\title{
Analysis of the Molecular Dialogue Between Gray Mold (Botrytis cinerea) and Grapevine (Vitis vinifera) Reveals a Clear Shift in Defense Mechanisms During Berry Ripening
}

\author{
Jani Kelloniemi, ${ }^{1}$ Sophie Trouvelot, ${ }^{1}$ Marie-Claire Héloir, ${ }^{1}$ Adeline Simon, ${ }^{2}$ Bérengère Dalmais, ${ }^{2}$ \\ Patrick Frettinger, ${ }^{1,3}$ Agnès Cimerman, ${ }^{2}$ Marc Fermaud, ${ }^{4}$ Jean Roudet, ${ }^{4}$ Sylvain Baulande, ${ }^{5}$ \\ Christophe Bruel, ${ }^{3}$ Mathias Choquer, ${ }^{3}$ Linhdavanh Couvelard, ${ }^{5}$ Mathilde Duthieuw, ${ }^{5}$ Alberto Ferrarini, ${ }^{6}$ \\ Victor Flors, ${ }^{7}$ Pascal Le Pêcheur, ${ }^{2}$ Elise Loisel, ${ }^{4}$ Guillaume Morgant, ${ }^{2}$ Nathalie Poussereau, ${ }^{3}$ \\ Jean-Marc Pradier, ${ }^{2}$ Christine Rascle, ${ }^{3}$ Lucie Trdá, ${ }^{1}$ Benoit Poinssot, ${ }^{1}$ and Muriel Viaud ${ }^{2}$ \\ ${ }^{1}$ Université de Bourgogne, UMR 1347 Agroécologie, Pôle Interactions Plantes Micro-organismes-ERL CNRS 6300, 17 rue \\ Sully, 21000 Dijon, France; ' ${ }^{2}$ NRA, UMR 1290 BIOGER, Avenue Lucien Brétignières, 78850 Grignon, France; ${ }^{3}$ UMR 5240 MAP, \\ Université Lyon 1-CNRS-Bayer CropScience, Villeurbanne, France; ${ }^{4}$ INRA, UMR 1065 Santé et Agroécologie du Vignoble, \\ 33882 Villenave d'Ornon, France; ${ }^{5}$ PartnerChip, 2 rue G. Crémieux, 91000 Evry, France; ${ }^{6}$ Università degli Studi di Verona, \\ Dipartimento di Biotecnologie, Strada Le Grazie 15, 37134 Verona, Italy; ${ }^{7}$ University of Jaume I, Plant Physiology Section, \\ CAMN, Castellón, 12071, Spain
}

Submitted 20 February 2015. Accepted 4 August 2015.

\begin{abstract}
Mature grapevine berries at the harvesting stage (MB) are very susceptible to the gray mold fungus Botrytis cinerea, while veraison berries (VB) are not. We conducted simultaneous microscopic and transcriptomic analyses of the pathogen and the host to investigate the infection process developed by $B$. cinerea on $\mathrm{MB}$ versus $\mathrm{VB}$, and the plant defense mechanisms deployed to stop the fungus spreading. On the pathogen side, our genome-wide transcriptomic data revealed that $B$. cinerea genes upregulated during infection of $\mathrm{MB}$ are enriched in functional categories related to necrotrophy, such as degradation of the plant cell wall, proteolysis, membrane transport, reactive oxygen species (ROS) generation, and detoxification. Quantitative-polymerase chain reaction on a set of representative genes related to virulence and microscopic observations further demonstrated that the infection is also initiated on VB but is stopped at the penetration stage. On the plant side, genome-wide transcriptomic analysis and metabolic data revealed a defense pathway switch during berry ripening. In response to $B$. cinerea inoculation, VB activated a burst of ROS, the salicylate-dependent defense pathway, the synthesis of the resveratrol phytoalexin, and cell-wall strengthening. On the contrary, in infected MB, the jasmonate-dependent pathway was activated, which did not stop the fungal necrotrophic process.
\end{abstract}

Grapevine is confronted by several severe diseases mainly caused by phytopathogenic fungi and oomycetes, including downy mildew (Plasmopara viticola), powdery mildew

Co-senior and co-corresponding authors: M. Viaud; Telephone +33 130814 568; E-mail: viaud@ versailles.inra.fr; and B. Poinssot; Telephone: +33 380 693 458; E-mail: benoit.poinssot@ dijon.inra.fr

*The $e$-Xtra logo stands for "electronic extra" and indicates that two supplementary figures and seven supplementary tables are published online.

This article is in the public domain and not copyrightable. It may be freely reprinted with customary crediting of the source. The American Phytopathological Society, 2015.
(Erysiphe necator), and gray mold (Botrytis cinerea). Against these diseases, modern sustainable viticulture aims to limit chemical treatments by using alternative strategies. One of them is to trigger grapevine resistance by eliciting its innate immunity. Plant innate immunity is governed by two main defense pathways (Boller and Felix 2009). The first, pathogen-associated molecular pattern (PAMP)-triggered immunity (PTI) is based on recognition of evolutionarily conserved PAMPs or microbe- or damage-associated molecular patterns by receptors called pattern recognition receptors (Jones and Dangl 2006). The second, effector-triggered immunity (ETI) is activated after the detection of pathogen effectors by the plant (Böhm et al. 2014; Zipfel 2014). ETI is highly specific, depends on resistance genes, and is usually accompanied by a hypersensitive response (HR) manifesting as localized cell death at the point of infection (Jones and Dangl 2006). For some pathogens, like B. cinerea, the use of an ETI-based strategy cannot be considered, as no major resistant gene has been found in grapevine or in any other host species. Both PTI and ETI activate plant signaling events (Garcia-Brugger et al. 2006; Jeworutzki et al. 2010; Tsuda and Katagiri 2010) leading to a large-scale transcriptome reprogramming (Denoux et al. 2008; Pitzschke et al. 2009). Plant hormones such as salicylate (SA), jasmonate (JA), and ethylene (ET) take part in fine-tuning the defense responses (Koornneef and Pieterse 2008; López et al. 2008). In Arabidopsis, the consensus is that the SA-dependent signaling pathway is required for defense against biotrophs, while the JA and ET pathways are important against necrotrophs (Glazebrook 2005). One outcome of these defense signaling pathways is the production of antimicrobial secondary metabolites, such as phytoalexins (Hammerschmidt 1999), cell-wall reinforcements, and pathogenesis-related (PR) proteins such as beta1,3 glucanases and chitinases (van Loon et al. 2006). In Vitaceae spp., the stilbene compounds resveratrol and its derivatives are the main phytoalexins produced via the phenylalaninepolymalonate pathway. The key enzymes are phenylalanine ammonia lyase (PAL) and stilbene synthase (STS), which condense one molecule of coumaroyl-CoA and three molecules 
of malonyl-CoA to produce resveratrol (Coutos-Thévenot et al. 2001).

The development of anti-Botrytis strategies based on elicitation of plant immunity requires a better knowledge of the molecular interaction between this fungus and grape. In vineyards in spring, $B$. cinerea may infect young leaves and, more often, the grapevine inflorescences (Elmer and Michailides 2007; Martinez et al. 2005). Green berries and berries that begin to ripen, i.e., the veraison stage berries (VB), are not susceptible to B. cinerea (Deytieux-Belleau et al. 2009). On the other hand, mature berries (MB) are highly susceptible to the pathogen (Elmer and Michailides 2007; Kretschmer et al. 2007), thus causing substantial damages to the phenolic and organoleptic properties of wines (Ky et al. 2012).

In recent years, the polyphagous fungus $B$. cinerea has become one of the most extensively studied necrotrophic fungal pathogens (Dean et al. 2012). This ascomycete is able to kill and feed on host cells through the production of unspecific toxins, reactive oxygen species (ROS) and a battery of lytic enzymes (Choquer et al. 2007; van Kan 2006). In addition, several studies strongly suggest that $B$. cinerea and other necrotrophic fungi induce the $\mathrm{HR}$ as part of their infection strategy (Dickman et al. 2001; Govrin and Levine 2000; Van Baarlen et al. 2007). Even though studies on B. cinerea have been conducted using several host plants, the infection molecular program initiated on vineyard berries remains unknown. On the plant side, the known defense mechanisms activated in grapevine berries by $B$. cinerea are still scarce
(Bézier et al. 2002; Derckel et al. 1998; Iriti et al. 2004; Monteiro et al. 2003; Robert et al. 2002; Robinson et al. 1997; Salzman et al. 1998).

The aim of this study was to provide the first integrated view of the fungal and plant molecular events during the early process of infection of grape berries by $B$. cinerea. Taking advantage of the availability of the complete genome sequences of $B$. cinerea and V. vinifera (Amselem et al. 2011; Jaillon et al. 2007; Velasco et al. 2007), we analyzed the transcriptomes of both organisms during the early stages of VB and $\mathrm{MB}$ infection. Together with microscopic observations and quantification of defense metabolites, this wide genomic approach was used to answer several questions. What are the molecular mechanisms deployed by $B$. cinerea for successful infection on MB? Are they also deployed on berries at the veraison stage? What might be the defense mechanisms used by grapevine berries to block the B. cinerea infection process at the veraison stage?

\section{RESULTS}

\section{Botrytis cinerea successfully infects mature berries} but not berries at the veraison stage.

Observations in vineyards and in vitro experiments suggest that VB are not susceptible to $B$. cinerea infection, whereas MB are highly susceptible (Deytieux-Belleau et al. 2009; Elmer and Michailides 2007; Kretschmer et al. 2007). We verified this difference on Vitis vinifera cv. Marselan by performing infection time series experiments on VB and MB harvested from the

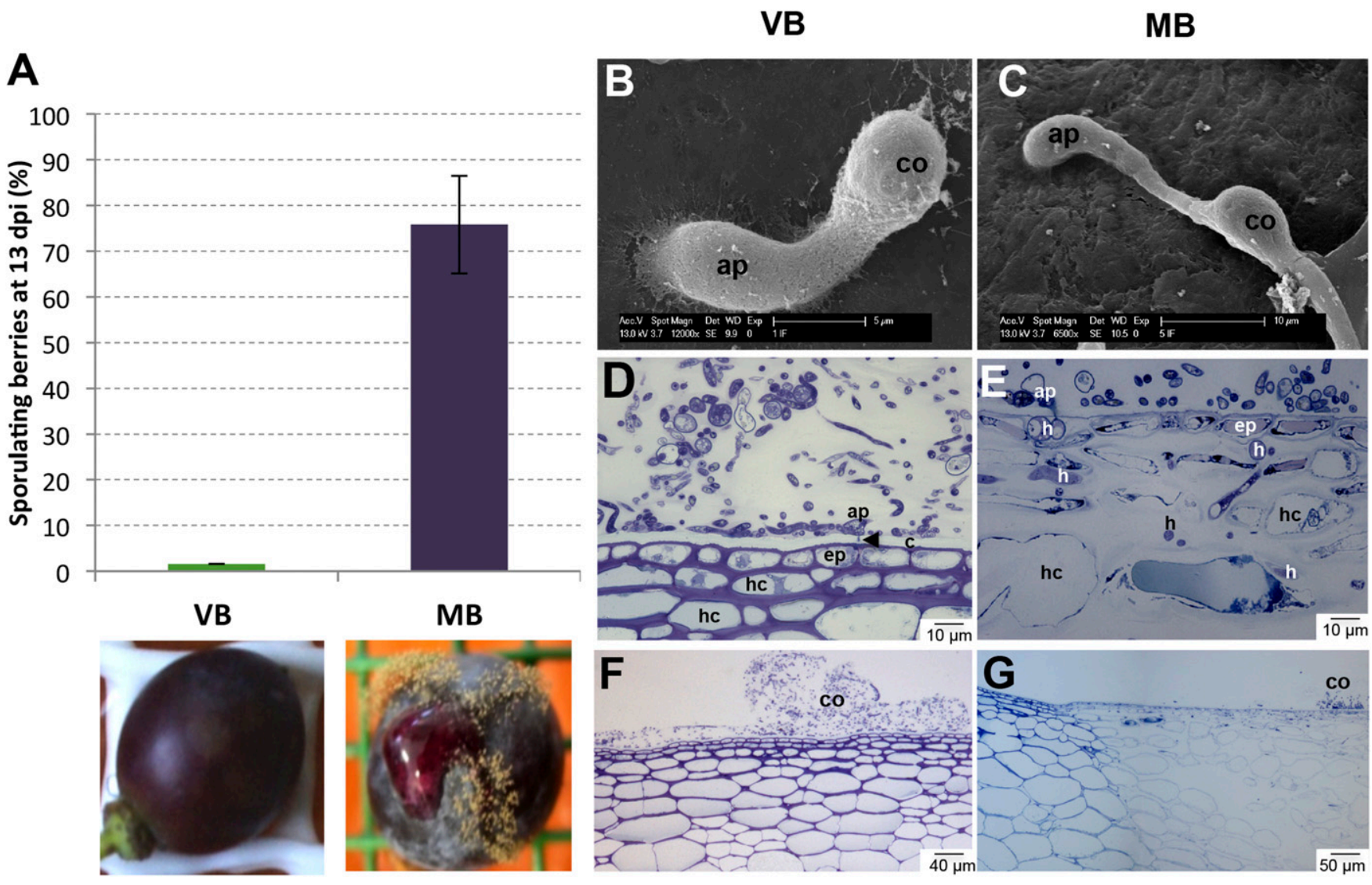

Fig. 1. Infection of grape berries by Botrytis cinerea. Berries at the veraison stage (VB) or mature berries (MB) were collected from the vineyards and inoculated with conidia of $B$. cinerea. A, Inoculation success as the percentage of berries with observed conidiophores at 13 days postinoculation and examples of infected VB (left) and MB (right). $\mathbf{B}$ and $\mathbf{C}$, Scanning electronic micrographs of conidia (co) germination and appressoria (ap) formation on VB and MB at $24 \mathrm{~h}$ postinoculation (hpi). D to G, Micrographs of toluidine blue-stained vertical thin sections of inoculated areas in VB (D and F) and MB (E and G) at 48 hpi. The decoloration in $\mathrm{E}$ and $\mathrm{G}$ around the site of inoculation site is due to host cell degradation. $\mathrm{c}=\mathrm{cuticule}$, ep $=$, epidermal cell, hc $=$ hypodermal cell, and $\mathrm{h}=$ fungal hyphae. All micrographs in B through $\mathrm{G}$ are representative views of 15 different observation zones. 
Bordeaux vineyards. The berries were thoroughly washed and were inoculated with conidia of the B05.10 B. cinerea strain and the infection process was followed at macro- and microscopic levels. Primary lesions were observed in MB between 48 to $72 \mathrm{~h}$ postinoculation (hpi). Spreading lesions were then observed between 72 and $96 \mathrm{hpi}$, with most of the MB bursting open at that point. Conidiophores became macroscopically visible between 96 and 120 hpi and sporulation was observed on $76 \pm$ $11 \%$ of the MB at 13 days postinoculation (dpi) (Fig. 1A). In contrast, lesions were not observed on the VB over the 13-day observation period and fewer than $2 \%$ of the VB showed macroscopically visible sporulation at $13 \mathrm{dpi}$. Microscopic observations showed that conidia germination led to formation of unicellular appressoria between 16 and $24 \mathrm{hpi}$ on both kinds of berries (Fig. 1B and C). Some multicellular appressoria, also called infection cushions, were also observed at 24 hpi and later (data not shown). Although conidia germination and appressoria formation proceeded similarly on the surface of $\mathrm{VB}$ and $\mathrm{MB}$, clear differences were observed within and below the berry cuticle at the site of inoculation at $48 \mathrm{hpi}$. On VB, fungal penetration pegs passed through only up to two thirds of the cuticle and no mycelium colonization was detected under the cuticle (Fig. 1D). B. cinerea did not penetrate in the first epidermal cell layer and all the lower cell layers of the berry looked healthy (Fig. 1F). In contrast, inoculation of $B$. cinerea on $\mathrm{MB}$ resulted in appressorium penetration through the cuticle and mycelium colonization between the cuticle and the epidermal outer wall and, finally, between the different deeper cell layers (Fig. 1E). In the MB, the areas with successful invasion were lightly stained with toluidine blue, suggesting cell degradation by the necrotroph (Fig. 1G).

All together, these observations suggest that $B$. cinerea initiated a similar infection process both on $\mathrm{MB}$ and VB but failed to further colonize the berries at veraison stage. The infection and defense processes involved in the host-pathogen early stages of infection were further investigated by parallel transcriptomic analyses.

\section{$B$. cinerea genes encoding virulence factors are upregulated during infection of both $\mathrm{VB}$ and $\mathrm{MB}$.}

The transcriptome of $B$. cinerea at 16, 24, and 48 hpi after inoculation of MB was investigated using NimbleGen wholegenome oligonucleotide arrays (Amselem et al. 2011) and was compared with mycelium grown in vitro. Principal component analysis of the data indicated that the three in planta conditions are close to each other while the in vitro mycelium control condition (M) is clearly apart (Supplementary Fig. S1). Differential expression analysis performed using a gene analysis of variance (ANOVA)-based method (Simon and Biot 2010) revealed 3,001 differentially expressed (DE) genes $(P$ value $<0.05$, fold change $>2$ ) whose expression patterns could be clustered into four main profiles (Fig. 2A; Supplementary Table S1). Functional enrichment analyses with defined sets of $B$. cinerea annotated genes (Amselem et al. 2011; Espino et al. 2010; Schumacher et al. 2014) were performed to reveal biological processes that are statistically overrepresented among each cluster (Supplementary Table S2).

Cluster 1 includes 1,344 genes that are upregulated at the three infection time points when compared with the in vitro growth, suggesting that they are involved in the infection process from the early stage of the time course (Fig. 2A). This first wave of in planta-upregulated genes is significantly enriched in genes encoding secreted proteases, such as the characterized aspartic proteases BcAP5, BcAP8, BcAP9, and BcAP14 (ten Have et al. 2010). There is also an enrichment in the genes encoding carbohydrate-active enzymes (Cantarel et al. 2009) corresponding to plant cell wall-degrading enzymes (CWDE) such as the endopolygalacturonase BcPG2 (BofuT4_P089000.1)
(Kars et al. 2005a) and the pectin methyl esterase BcPME2 (BofuT4_P021040) (Kars et al. 2005b). In total, 50 proteins in cluster 1 , including proteases and CWDE, were previously identified in the secretome of B. cinerea (Espino et al. 2010). Genes in cluster 1 also suggest the activation of enzymes involved in the generation and detoxification of ROS. Notably, several genes encode ROS scavengers that protect the fungus against the oxidative burst, i.e., the superoxide dismutase BcSOD1 (BofuT4_P021610.1) (Rolke et al. 2004) and several peroxidases and enzymes belonging to the glutathione system (Heller and Tudzynski 2011). Lastly, genes involved in primary metabolism and respiration, such as mitochondrial carrier-encoding genes, are enriched to a lesser extent.

Cluster 2 includes 544 genes that are progressively upregulated between 24 and 48 hpi (Fig. 2A). This second wave of gene expression is mainly enriched in those encoding membrane transporters, both of the ATP-binding cassette (ABC) and the major facilitator family (MFS) types, including some predicted to allow sugar efflux. An enrichment was also observed for genes encoding proteases and ROS scavengers, such as BcGST1 (BofuT4_P103600.1) (Prins et al. 2000).

Cluster 3 includes 80 genes that are downregulated at $16 \mathrm{hpi}$ but whose expression increases at 48 hpi. Finally, cluster 4 comprises 1,033 genes that are downregulated on MB (compared with the in vitro growth control), suggesting that these genes are involved in biological processes that are more important during saprophytic development than during infection. No functional category was significantly enriched in these two last clusters.

Gene-enrichment analysis, therefore, suggested that $B$. cinerea requires CWDE, proteases, ROS producers and scavengers, and membrane transporters to perform grape berry infection. In addition, genes encoding other known or suspected virulence factors were identified among the genes upregulated in planta. Notably, secondary metabolism gene clusters responsible for the biosynthesis of the botcinic acid and botrydial phytotoxins (BCBoa and BcBot genes, respectively) were identified. The $B c B o a 6$ gene encoding a polyketide synthase (PKS) acting as the key enzyme for botcinic acid synthesis and five other colocalized genes (BcBoa3, BcBoa5, BcBoal1, BcBoal4, and BcBoa17) (Dalmais et al. 2011) belong to cluster 2. The BcBot1 gene that encodes a P450 monooxygenase essential for botrydial production (Siewers et al. 2005) and the BcBot5 colocalized gene belong to cluster 3 . Genes involved in abscisic acid (ABA) synthesis (Siewers et al. 2006) are part of clusters 2 (BcAbal and $B c A b a 4)$ and 3 (BcAba2). Additionally, the $B c P k s 8$ gene, encoding a PKS (Kroken et al. 2003), is significantly overexpressed from 16 hpi (cluster 1), as is the colocalized ABC transporter gene (BofuT4_P118990.1) that likely participates in the export of the polyketide. In addition, the data suggested that proteins with phytotoxic activities are produced during MB infection. The gene encoding the necrosis-and-ethyleneinducing proteins BcNEP1 (BofuT4_P070460.1) and BcNEP2 (BofuT4_P066710.1) (Schouten et al. 2008) and the ceratoplatanin family protein BcSPL2 (BofuT4_P000440.1) (Frías et al. 2011) are upregulated during infection (clusters 1 and 2).

The transcriptome of $B$. cinerea on VB at 16,24 , and 48 hpi could not be investigated using microarrays, due to the limited amount of fungal RNA compared with the plant RNA (below $20 \%$ of the total RNA extracted from infected tissues [data not shown]). To overcome this technical bottleneck, a quantitative polymerase chain reaction (qPCR) approach was used. We selected six genes encoding known virulence factors (BcPg2, BcBoa6, BcSod1) or proteins expected to contribute to the infection program (BcPme2, BcNep2, BcGst1) among the genes identified as upregulated during the infection of MB (clusters 1 and 2) and investigated their expression on VB and $\mathrm{MB}$ that were harvested independently from those used for 
microarrays (i.e., another year). qPCR confirmed that all six genes were upregulated on MB (Fig. 2B). Moreover, these genes were also shown to be upregulated at 16 and 24 hpi on VB. At 48 hpi, significant differences in the expression pattern appeared between VB and $\mathrm{MB}$ (except for $\mathrm{BcPg}$ 2) that could be linked to the fact that the $B$. cinerea infection process is stopped in VB. Genes encoding the ROS scavengers BcSOD1 and BcGST1 are significantly overexpressed at 24 and $48 \mathrm{hpi}$ on VB compared with MB, suggesting that the fungus encounters a stronger oxidative burst on VB.

In order to test whether the $B$. cinerea upregulated genes are essential for the infection process on grape berries, several corresponding knock-out (KO) mutants were inoculated on $\mathrm{MB}$, and the disease progression was compared with the wild- type (WT) strain. Conidial suspensions of the metabolitedeficient mutants bcbot $2 \Delta$ (Pinedo et al. 2008), bcboa6s, bcbot $2 \Delta /$ bcboa6 $\Delta$ (Dalmais et al. 2011), bcabals (Siewers et al. 2004), and bcpks $8 \Delta$ were inoculated on MB and the rate of 'berry bursting' due to tissue maceration was measured daily (Supplementary Table S3). The simple KO mutants were as virulent as the WT strain, while the bcbot $2 \Delta /$ bcboa $6 \Delta$ double mutant was partly impaired in its ability to induce burst of berries and to colonize them, as previously observed on other host tissues (Dalmais et al. 2011). Additionally, the bcsodls mutant, which was previously shown to be impaired in the colonization of bean leaves (Rolke et al. 2004), was slightly reduced in infection on MB. In conclusion, although these genes are upregulated during the infection, the characterization of the
A
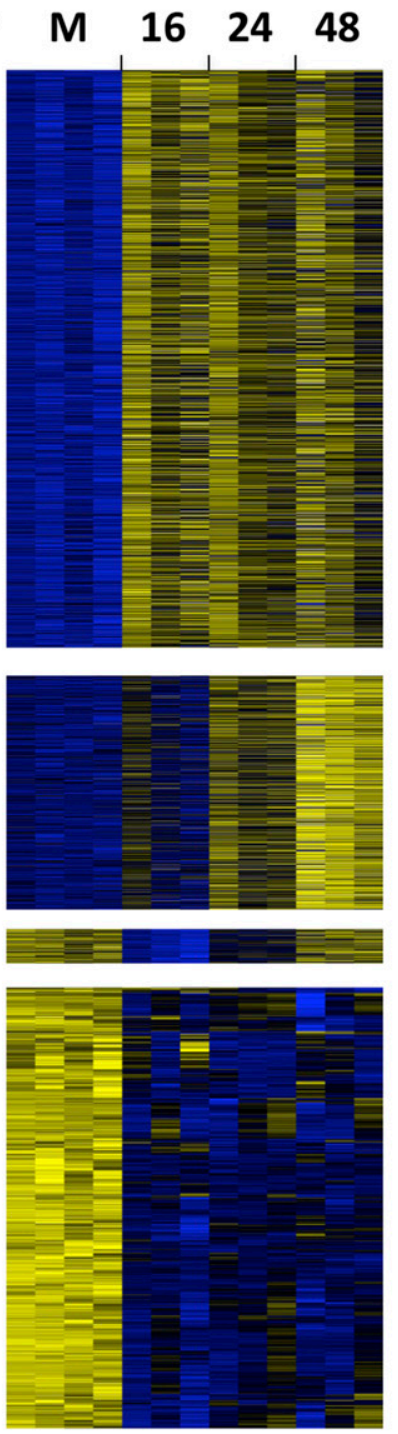

Cluster 2 (544 genes):

- Transporters

- Proteases

- Proteins involved in ROS detoxification

Significantly enriched functions :

Cluster 1 (1344 genes):

- Secreted proteases

Plant cell wall degrading enzymes

Proteins involved in ROS generation and detoxification

Proteins involved in primary metabolism and respiration

Cluster 3 (80 genes)

Cluster 4 (1033 genes)
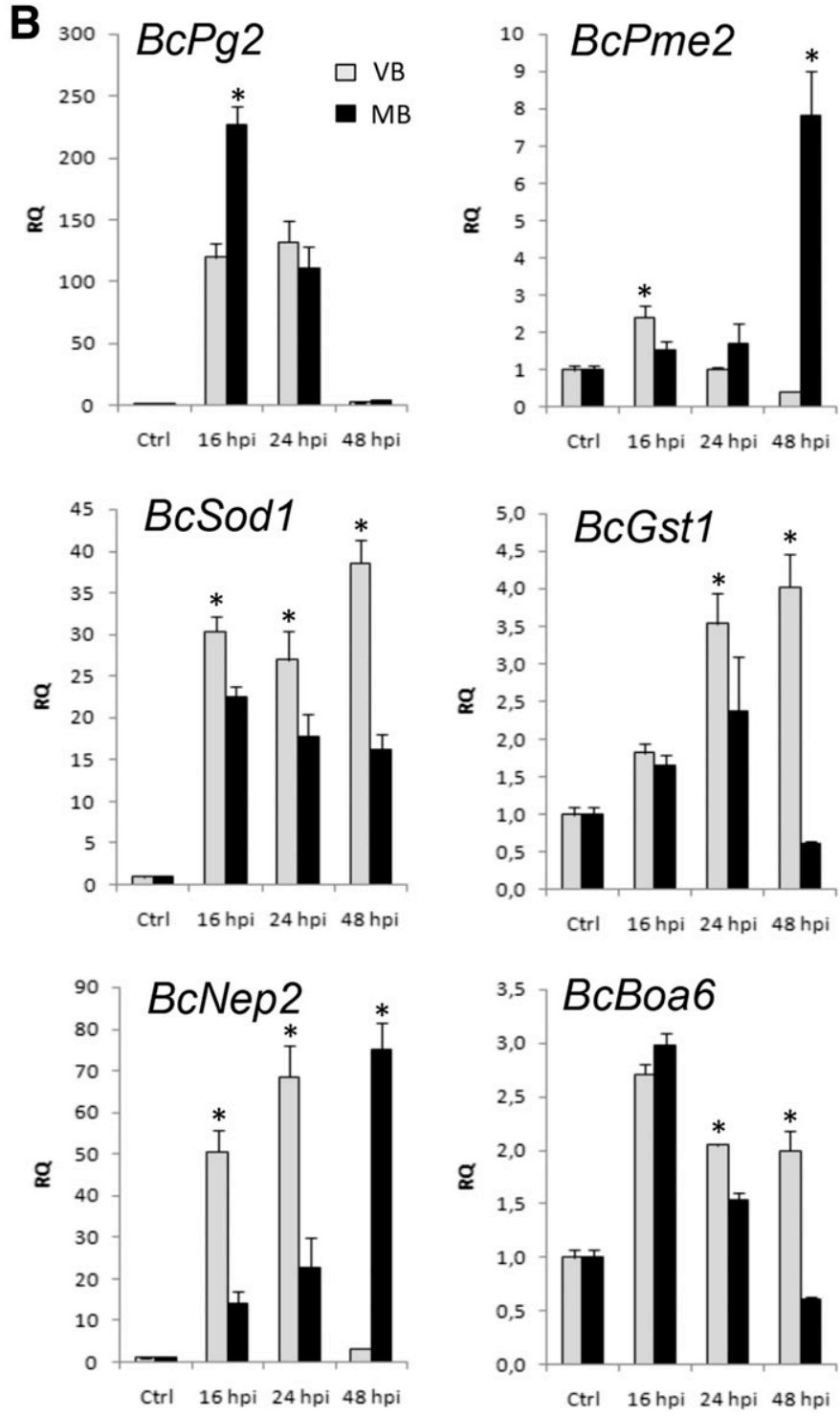

Fig. 2. Expression profiling of differentially expressed (DE) Botrytis cinerea genes during the early infection of mature grape berries (MB). A, Heatmap of the $3,001 \mathrm{DE}$ genes $(P<0.05$, fold-change $>2)$ during infection of MB by comparing NimbleGen arrays data at 16,24 , and $48 \mathrm{~h}$ postinoculation (hpi) and in vitro mycelium (M). Three biological experiments were realized per in planta condition and four repetitions were realized for the in vitro mycelium. Relative expressions (i.e., $\log 2$-normalized intensities scaled by gene) of the genes in the four conditions were clustered and depicted by color scale, where shades of blue represent underexpressed genes and shades of yellow represent overexpressed genes. Enrichments among clusters were calculated using the lists of functionally annotated genes described by Amselem et al. (2011) and Schumacher et al. (2014) and a standard Fisher test. Only the lists with $P<0.05$ and an odds ratio $>2$ were considered as significantly overrepresented. B, Expression of six virulence-related genes in the veraison stage (VB) or MB. Gene expression levels were determined by quantitative polymerase chain reaction following the $2^{-\Delta \Delta C T}$ method, using the constitutively expressed actin gene $B c A c t 1$ as a reference. RQ is the relative quantity calculated as gene expression at 16,24 , and $48 \mathrm{hpi}$, compared with in vitro mycelium (Ctrl). The error bar is the standard error of the mean of three biological replicates. Asterisks $(*)$ indicate statistically significant difference between infected MB and VB samples $(P<0.05)$, using unpaired heteroscedastic Student's $t$ test. Light gray and black columns represent VB and MB, respectively. 
corresponding KO mutants did not reveal a major role in infection of grape berries.

\section{VB and MB differ in their transcriptome reprogramming during $B$. cinerea infection.}

Grapevine Nimblegen arrays were used both to investigate the transcriptome of infected $\mathrm{MB}$ (simultaneously to $B$. cinerea transcriptome described above) and to compare it with the transcriptome of infected VB. When compared with the basal expression level ( $0 \mathrm{hpi}$ ), the numbers of $V$. vinifera genes significantly deregulated (induced or repressed) by the infection were higher in $\mathrm{MB}$ than in VB $(P$ value $<0.05$, fold change $>2)$ (Fig. 3A). A total of 3,025 DE genes were found in $\mathrm{MB}$, whereas only 159 DE genes were found in VB (Fig. 3B). About $90 \%$ of the DE genes were found at both 24 and 48 hpi in VB, whereas a large increase in DE genes was observed from 24 to $48 \mathrm{hpi}$ in MB. Only nine DE genes were found to be commonly regulated in both the inoculated $\mathrm{VB}$ and $\mathrm{MB}$ at both 24 and 48 hpi (Fig. 3B; Supplementary Table S4). Five of them were predicted to encode very similar germin-like proteins (GLPs) classified as VvGLP4 and VvGLP4-like according to Godfrey et al. (2007). Furthermore, 23 common genes showed a delayed induction in $\mathrm{MB}$ as they were found to be significantly deregulated in VB already at $24 \mathrm{hpi}$ but at $48 \mathrm{hpi}$ in MB (Fig. 3B). Notable genes in that group were another four $V v G L P 4$-like genes, $V v G L P 3$, five terpene synthase-encoding genes, and two genes encoding nitrilase and nitrile hydratases putatively involved in indole 3 -acetic acid synthesis. The $V v G L P$ transcripts were among the most highly induced genes in the inoculated VB skin tissue at 24 and 48 hpi (Fig. 3C). Interestingly, the SA-marker gene $V v P R l$ was the most induced in inoculated VB data, whereas transcripts of different enzymes of the JA biosynthesis (phospholipase, lipase, allene oxide synthase, jasmonate $O$-methyltransferase) were induced in MB data.

Hierarchical clustering of the DE genes among all conditions resulted in 15 clusters that were subsequently put through gene ontology (GO) analysis (Fig. 3C). The DE genes upregulated strongly in infected VB grouped into clusters 3, 4, 5, and 7. Cluster 3 is enriched in genes encoding extracellular proteins (21 in total). Twelve of them encode GLPs, including the ones mentioned above and five encode PR proteins (two PR1s, a PR3 endochitinase, and a PR5 thaumatin-like). Cluster 5 is also enriched in genes encoding extracellular proteins (aspartic proteinase and polygalacturonase inhibitor) and receptor kinases (a cysteine-rich receptor like kinase, a leucine-rich
A

VB 24

VB 48

MB 24

MB 48

936
$54 \square 93$

$55 \square 100$
B

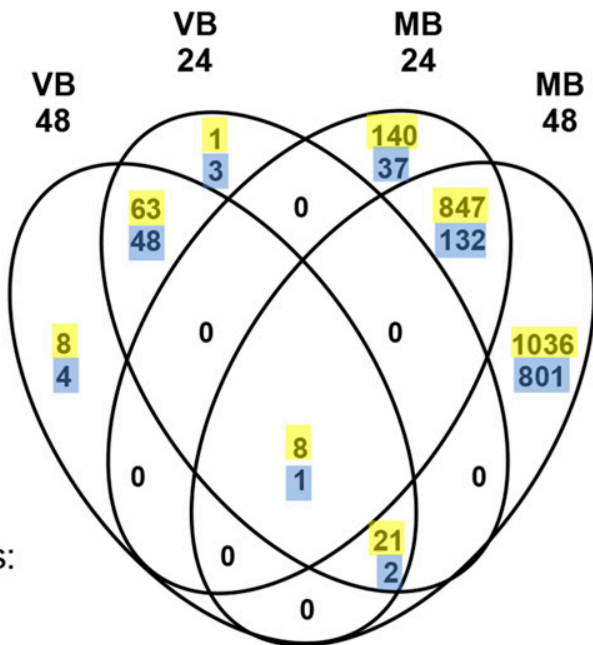

VB VB VB MB MB MB $\begin{array}{lllllll}0 & 24 & 48 & 0 & 24 & 48\end{array}$

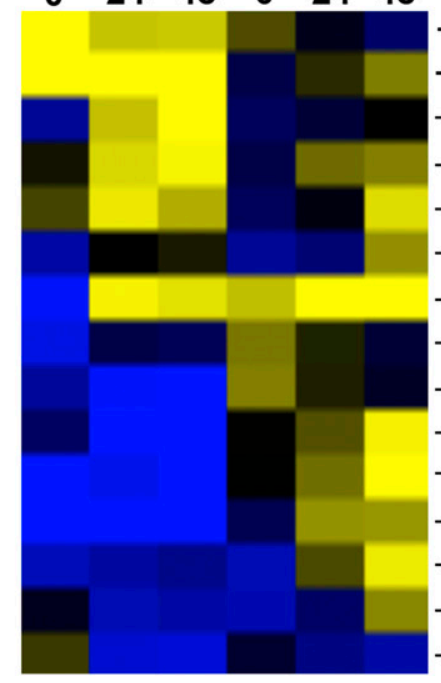

Significant GO-terms within clusters:

1912
- C1 (518)

C2 (99)

C3 (118) $\rightarrow$ ExR (GLPs, PR1s, PR3, PR5)

C4 (49)

C5 $(75) \rightarrow$ ExR (Proteinases, PGIP); Receptor activity (RPKs)

C6 $(68) \rightarrow$ Receptor activity (RPKs)

C7 (143) $\rightarrow$ Response to stimulus (STSs); Lyase activity (PALs, Terpene synthases)

C8 (254)

C9 (182) $\rightarrow$ ExR (GDSL-esterases/lipases, expansins, peptide toxins)

- C10 (133) [ExR (Laccases. Peroxidases)

- C11 (753)

C12 (513) $\rightarrow$ Cell death (R-genes) Catabolic process (PR3s, Laccases, Peroxidases) Receptor activity (RPKs)

C13 (67)

C14 (135)

C15 (42)

Fig. 3. Analysis of the transcriptomic data of veraison-stage berries (VB) and mature grape berries (MB) infected by Botrytis cinerea. A, Numbers of differentially expressed (DE) genes $(P<0.05$, fold-change $>2$ ) either upregulated (yellow) or downregulated (blue) during infection. B, Venn diagram showing the number of DE genes unique to or common within the four conditions. The top and bottom numbers correspond to the up- and downregulated genes, respectively. C, Hierarchical clustering of the DE genes using log2-transformed averages of the normalized fluorescence intensities of the three biological replicates per modality. The number of genes in each cluster $(\mathrm{C} 1$ to $\mathrm{C} 15)$ is in parentheses. ExR $=$ extracellular region, GLP $=$ germin-like protein, $\mathrm{PR}=$ pathogenesis-related, PGIP $=$ polygalacturonidase-inhibiting protein, $\mathrm{RPK}=$ receptor-like protein kinase, $\mathrm{STS}=$ stilbene synthase, $\mathrm{PAL}=$ phenylalanine ammonia lyase, and $\mathrm{R}=$ resistance. 
repeat [LRR]-receptor-like $\mathrm{S} / \mathrm{T}$ protein kinase, a putative receptor kinase). Cluster 7 groups genes highly induced during $B$. cinerea infection not only in VB but also in MB. It is enriched in genes encoding proteins belonging to the 'response to stimulus' GO group, such as putative STS (29 copies), and to the 'lyase activity' GO group, such as putative PAL (seven copies) and terpene synthases (five copies). The DE genes downregulated in VB were found in clusters 1, 9, 10, 14, and 15. Among them, only cluster 9 is enriched in genes encoding extracellular proteins, such as GDSL esterase/lipases and expansins.

Clusters 6, 10, 11, 12, 13, and 14 contain DE genes that are upregulated in infected MB but show little expression in inoculated VB. Clusters 6 and 11 are enriched in genes belonging to the 'receptor activity' GO group, with many of them encoding cysteine-rich receptor-like kinases. Cluster 11 is also enriched in genes encoding extracellular proteins and proteins with oxidoreductase activity, including laccase-like proteins (30), peroxidases (11), and cytokinin dehydrogenases (five). Lastly, cluster 12 is enriched in genes associated with cell death. A total of 44 such genes were found and all of them were putative $\mathrm{R}$ protein-encoding genes with toll interleukin 1 receptor-coiled coil nucleotide binding site LRR-domains, many of them resembling either $R P P 13$, which confers downy mildew resistance in A. thaliana or $N$ of Nicotiana glutinosa, granting resistance to Tobacco mosaic virus.

In conclusion, the whole transcriptome analysis of infected VB versus infected MB suggested that different defense mechanisms could be involved. These differences were further investigated by qPCR and by quantification of the corresponding metabolites.

\section{ROS are rapidly produced in inoculated VB.}

In the Botrytis-induced grapevine transcriptomes, genes encoding $\mathrm{H}_{2} \mathrm{O}_{2}$-producing VvGLPs (Godfrey et al. 2007) were expressed both earlier and more strongly in VB than in MB. Subsequent qPCR on independent berry samples infected by $B$. cinerea indicated that genes encoding the putative superoxide generating NADPH-oxidase VvRbohD (Dubreuil-Maurizi et al. 2010; Gauthier et al. 2014) and VvGLP3 are induced on $\mathrm{VB}$ at 24 and $48 \mathrm{hpi}$, respectively (Fig. 4A). To confirm the suspected increased amounts of $\mathrm{H}_{2} \mathrm{O}_{2}$ in infected $\mathrm{VB}, 3,3$ diaminobenzidine (DAB) staining of berry peel samples were performed at 72 hpi (Fig. 4B through G). Numerous spots of reddish-brown DAB precipitates were observed in inoculated areas of VB (Fig. 4B). Furthermore, colocalization of DAB-stained single epidermal cells and pathogen appressoria were observed (Fig. 4D and F). In comparison, no evidence of $\mathrm{H}_{2} \mathrm{O}_{2}$ could be observed on $\mathrm{MB}$, in which $B$. cinerea had developed more multicellular appressoria (Fig. 4C, E, and G).

\section{The SA/JA hormonal balance differs between Botrytis-infected VB and MB.}

Microarray results suggested that several JA marker genes were upregulated in the inoculated $\mathrm{MB}$, whereas SA marker genes were upregulated in VB only. Transcript expression
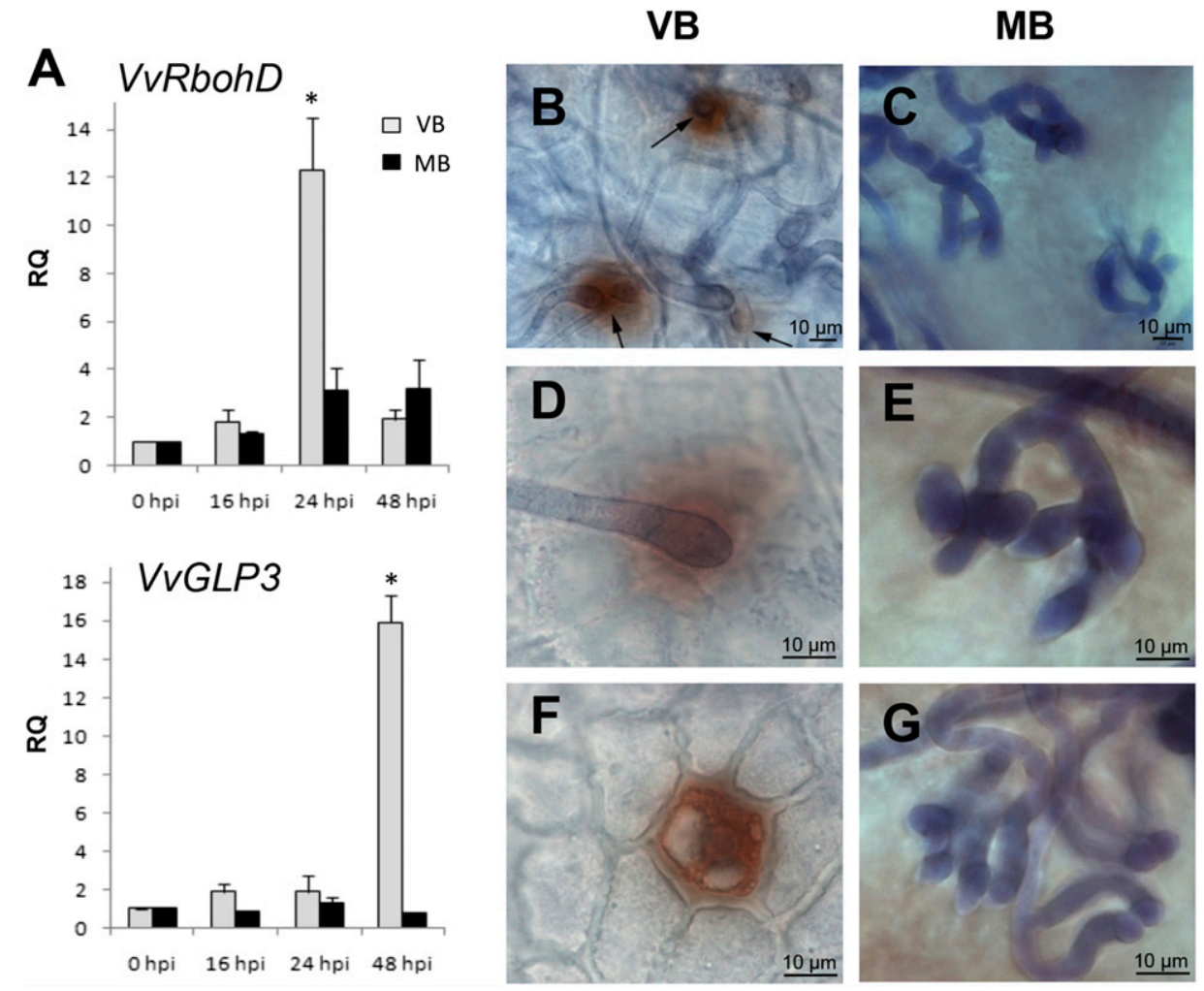

Fig. 4. Reactive oxygen species in Botrytis cinerea-infected veraison stage berries (VB) and mature grape berries (MB). A, Expression of genes encoding the NADPH oxidase VvRbohD that produces $\mathrm{O}_{2}^{-}$and the germin-like protein VvGLP3 that is a superoxide dismutase converting $\mathrm{O}_{2}^{-}$into $\mathrm{H}_{2} \mathrm{O}_{2}$. Gene expression levels were determined by quantitative polymerase chain reaction following the $2^{-\triangle \Delta C T}$ method, using the constitutively expressed gene $V v A T P 16$ as a reference. RQ is the relative quantity calculated as gene expression of inoculated samples compared with mock-inoculated samples at the same time point and compared with time 0 , set as 1 . The error bar is the standard error of the mean of three biological replicates. Asterisks $(*)$ indicate statistically significant differences between infected MB and VB samples $(P<0.05)$, using unpaired heteroscedastic Student's $t$ test. Light gray and black columns represent VB and $\mathrm{MB}$, respectively. B to G, 3,3-Diaminobenzidine staining (brown precipitate) to detect $\mathrm{H}_{2} \mathrm{O}_{2}$ production on inoculated berries at $72 \mathrm{~h}$ postinoculation (hpi). On VB (B, D, and F), many appressoria (arrows) coincided with brown-stained single epidermal cells directly under them (F is a deeper optical section of D), in contrast to MB samples (C, E, and G), in which this colocalization was never observed. 
measured by qPCR confirmed the specific induction of the SA marker gene $V v P R l$ in $\mathrm{VB}$, whereas the JA marker gene $V v J A Z l$ was specifically induced in MB (Fig. 5A). To confirm these results, the amounts of free SA and JA-isoleucine (JA-Ile) were quantified by liquid chromatography-mass spectrometry (LC-MS) in VB and MB peel samples during B. cinerea infection. Although the SA level in VB was not significantly induced by infection, its basal level (at $0 \mathrm{hpi}$ ) was around 10-fold higher than in MB (Fig. 5B). Regarding JA-Ile, its initial amount in $\mathrm{MB}$ was approximately 10-fold higher than in $\mathrm{VB}$ and it significantly increased after $B$. cinerea inoculation.

Production of resveratrol is highly induced in infected VB.

Microarray data also suggested that two defense-related parts of the plant phenylpropanoid pathway, the ones leading to stilbenes (resveratrol and its derivates) and lignin production, were induced in inoculated VB. Using qPCR, we confirmed that $V v P A L$ and $V v S T S$ were strongly expressed in inoculated VB at 16 and 24 hpi (Fig. 6A). This expression pattern fitted with the quantification of resveratrol; its amount had quadrupled from the basal level to approximately $65 \mu \mathrm{g}$ per gram of dry weight at $48 \mathrm{hpi}$ in VB, while its amount decreased 2.5-fold during the same time period in $\mathrm{MB}$ (Fig. 6B).
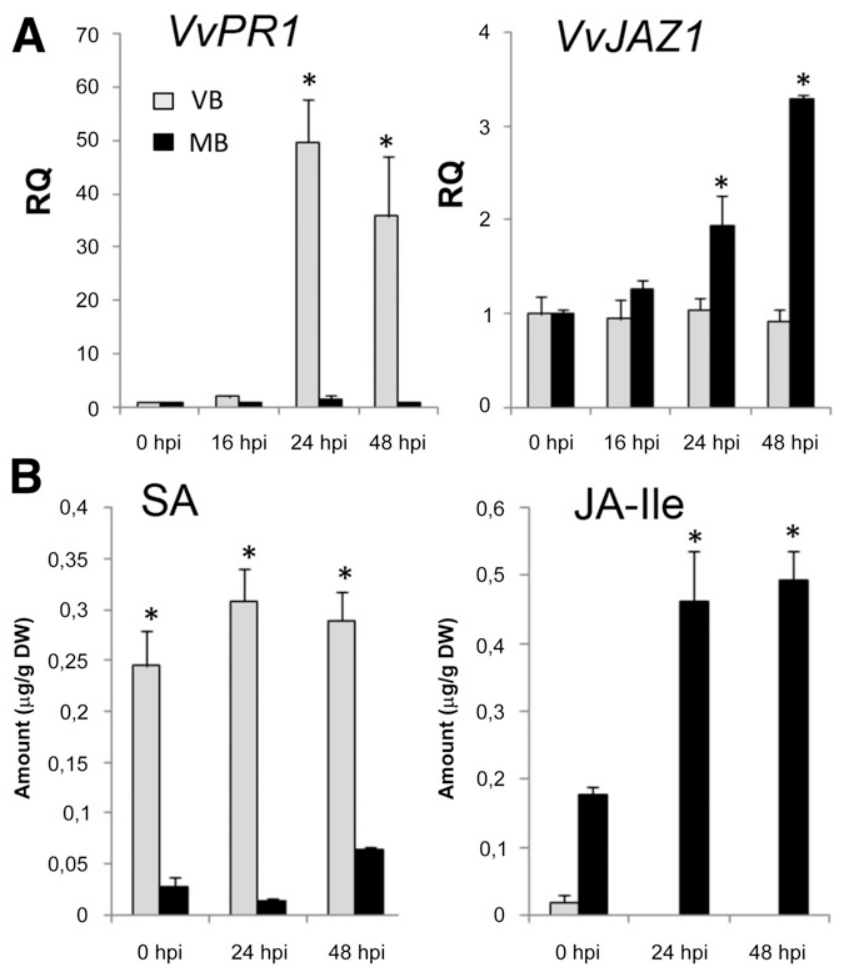

Fig. 5. Salicylic acid (SA)- and jasmonic acid (JA)-dependent pathways in Botrytis cinerea-infected veraison stage berries (VB) and mature grape berries (MB). A, Expression of the SA marker gene $V v P R 1$ and the JA marker gene $V v J A Z 1$ encoding the jasmonate ZIM-domain protein 1. Gene expression levels were determined by quantitative polymerase chain reaction following the $2^{-\Delta \Delta C T}$ method, using the constitutively expressed gene $V v A T P 16$ as a reference. RQ is the relative quantity calculated as transcript amount in inoculated samples compared with mock-inoculated samples at the same time point and compared with time 0 , set as 1 . The error bar is the standard error of the mean of three biological replicates. Light gray and black columns represent VB and MB, respectively. B, Amounts of SA and JA-isoleucine quantified by liquid chromatography-mass spectrometry. The error bar is the standard error of the mean of three biological replicates. Asterisks $(*)$ indicate statistically significant difference between infected MB and VB samples $(P<0.05)$, using unpaired heteroscedastic Student's $t$ test.
VB reinforce cell walls after contact with $B$. cinerea.

The penetration of the $B$. cinerea infectious hyphae through the cuticle of VB was blocked by 48 hpi (Fig. 1F), suggesting that secondary cell-wall strengthening might have been activated in the plant. In order to test this hypothesis, two grapevine genes encoding putative enzymes of the monolignol pathway were tested by qPCR: i) the $p$-coumarate 3-hydroxylase $(\mathrm{VvC} 3 \mathrm{H})$ and ii) the cinnamoyl CoA reductase $(V v C C R)$. Transcripts of $V v C C R$ and $V v C 3 H$ were specifically upregulated in response to $B$. cinerea on VB while they were negatively regulated in inoculated MB (Fig. 7A). The expression of these ligninassociated genes positively correlated with amounts of the corresponding metabolites (caffeic acid, ferulic acid, and chlorogenic acid) that specifically accumulated in VB (Fig. 7B).

In tomato and bean, plant cell-wall strengthening can also result from increased cross-linking of pre-existing extensins in the cell wall in response to fungal elicitors (Bradley et al. 1992; Brady and Fry 1997). An orthology-based search led to the identification of a grapevine gene encoding a proline-rich extensin-like protein (VvEXT), and both the microarray data and qPCR experiments from independent biological experiments showed that this gene was highly upregulated in the VB (Fig. 7A). All together, the transcript and metabolite quantifications indicate that specific cell-wall reinforcement is activated in VB
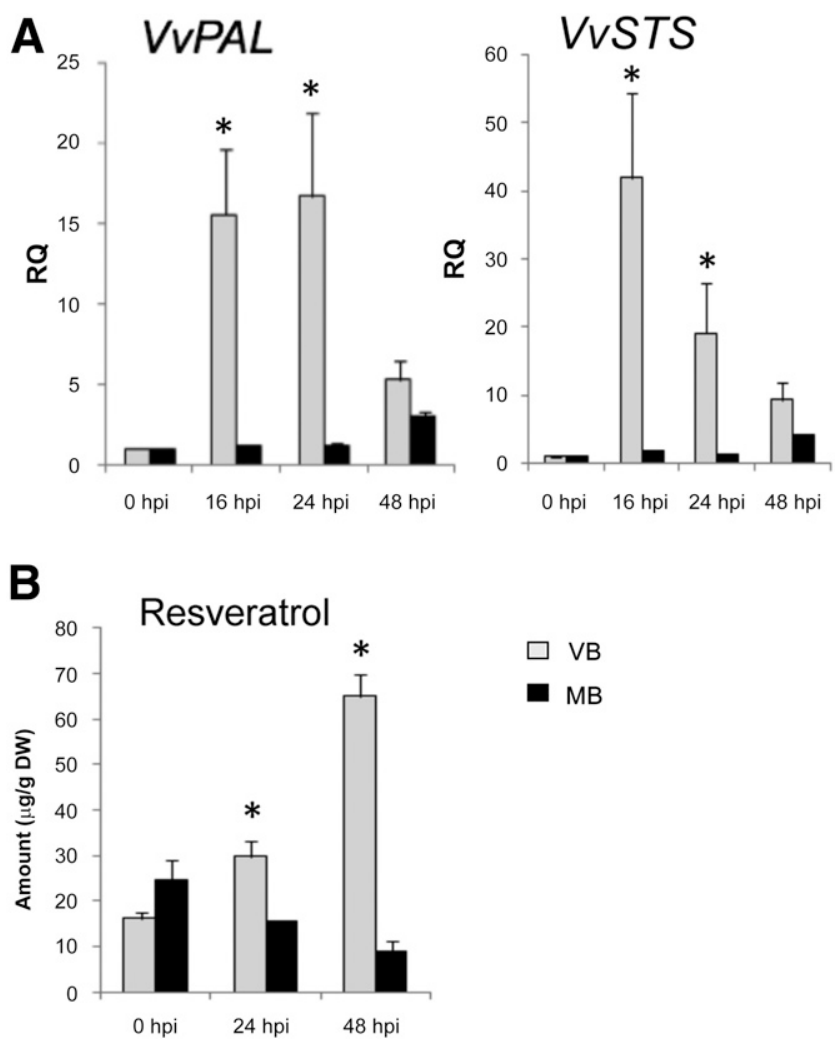

Fig. 6. Resveratrol-related pathway in Botrytis cinerea-infected veraison stage berries (VB) and mature grape berries (MB). A, Expression of the phenylalanine lyase $(V v P A L)$ and the stilbene synthase $(V v S T S)$ genes leading to the production of resveratrol. Gene expression levels were determined by quantitative polymerase chain reaction following the $2^{-\Delta \Delta C T}$ method, using the constitutively expressed gene $V v A T P 16$ as a reference. $\mathrm{RQ}$ is the relative quantity calculated as gene expression of inoculated samples compared with mock-inoculated samples at the same time point and compared with time 0 , set as 1 . The error bar is the standard error of the mean of three biological replicates. Light gray and black columns represent $\mathrm{VB}$ and $\mathrm{MB}$, respectively. B, Amounts of resveratrol quantified by liquid chromatography-mass spectrometry. Asterisks (*) indicate statistically significant differences between infected MB and VB samples $(P<0.05)$, using unpaired heteroscedastic Student's $t$ test. 
during $B$. cinerea infection. Microscopic analysis further indicated that papillae (thickenings of the cell wall) were formed beneath the appressoria in VB (Fig. 7C). In comparison, no papillae could be detected during early fungal infection on $\mathrm{MB}$ (Fig. 7D).

\section{DISCUSSION}

Despite the important economic impact of gray mold disease on grapevine, the details of infection of $B$. cinerea on this host have remained largely unknown. Our study provides the first overview of the $B$. cinerea transcriptome during the early stages of infection, i.e., penetration of the cuticle and necrosis of the first plant cells of mature berries (MB). When compared with the transcriptome of in vitro mycelium, 1,888 $\mathrm{B}$. cinerea genes were overexpressed during penetration and early colonization of MB (clusters 1 and 2) and 80 genes were first downregulated and then upregulated (cluster 3). Functional annotation of these upregulated genes confirmed that plant CWDE, proteases, ROS producers and scavengers, phytotoxic proteins, and secondary metabolites, such as botrydial and botcinic acid, are significant components of the $B$. cinerea infection machinery. From the previously characterized virulence factors, we investigated the botrydial and botcinic acid biosynthesis enzymes (Dalmais et al. 2011) and the superoxide dismutase SOD1 (Rolke et al. 2004). Also, a new putative virulence factor, i.e., PKS8, was studied. However, none of the corresponding KO mutants (bcbot $2 \Delta$, bcboa $6 \Delta$, bcabal $\Delta$, bcsod $1 \Delta$, and bcpks $8 \Delta$ ) showed a significant virulence defect on the harvested MB. Only the bcbot $2 \Delta /$ bcboa $6 \Delta$ double mutant was partly impaired, confirming the redundant roles of the phytotoxins (Dalmais et al. 2011). Redundancy between virulence factors may be the reason for the lack of a significant decrease of virulence of the other single KO mutants. Although the pathogenicity test we used indicated that none of the tested genes were essential for grape berry infection, these genes may contribute to the infection process. B. cinerea genes upregulated during the infection of sunflower leaves (48 hpi) were also enriched in those encoding
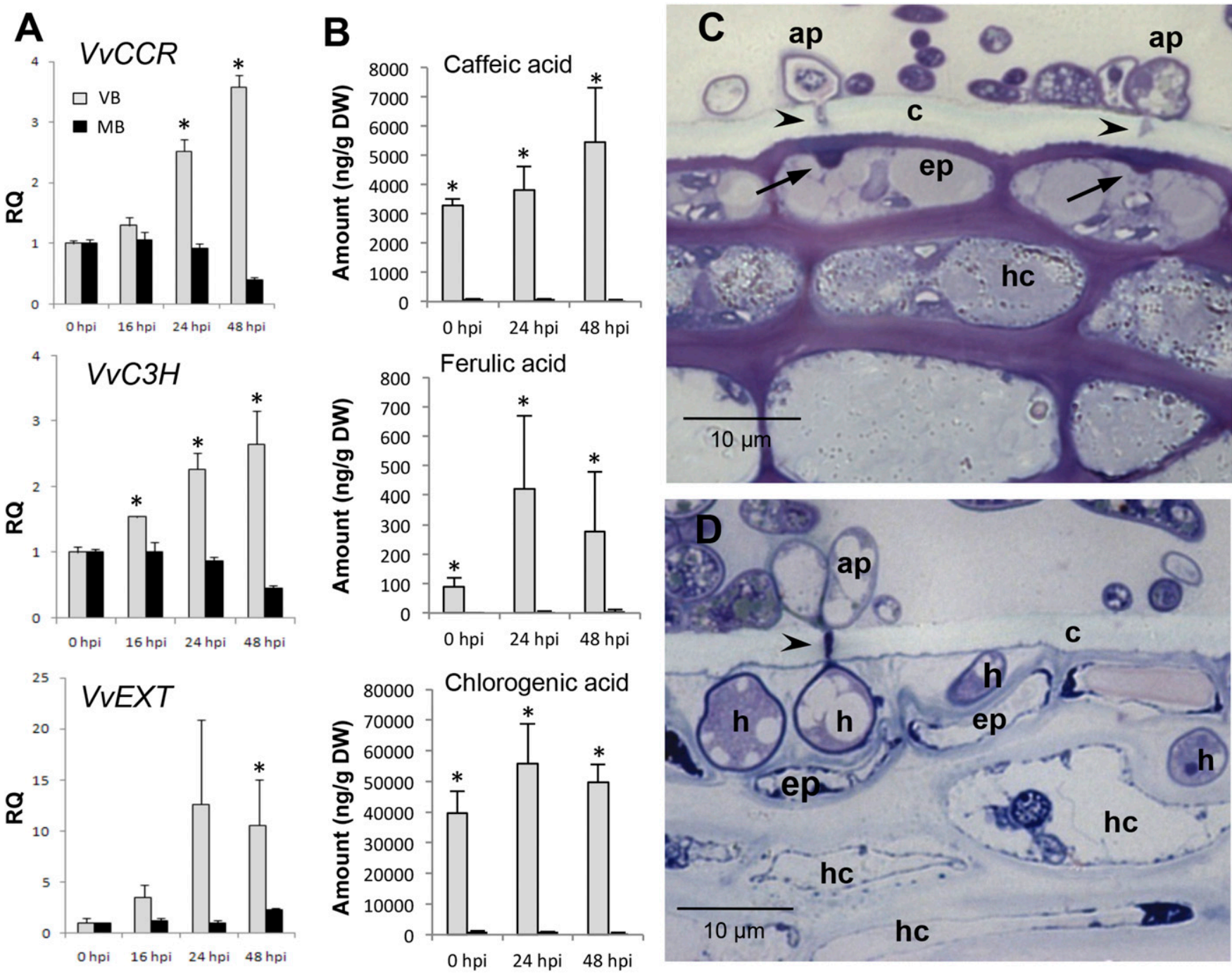

Fig. 7. Cell-wall reinforcement in Botrytis cinerea infected-veraison stage berries (VB) and mature grape berries (MB). A, Expression of genes encoding the cinnamoyl-CoA reductase $(V v C C R)$ and $p$-coumarate 3-hydroxylase $(V v C 3 H)$ that are involved in lignin biosynthesis and the extensin-like protein $(V v E X T)$. Gene expression levels were determined by quantitative polymerase chain reaction following the $2^{-\Delta \Delta C T}$ method, using the constitutively expressed gene VvATP16 as a reference. RQ is the relative quantity calculated as gene expression of inoculated samples compared with mock-inoculated samples at the same time point and compared with time 0, set as 1. Light gray and black columns represent VB and MB, respectively. B, Amounts of caffeic, ferulic, and chlorogenic acid quantified by liquid chromatography-mass spectrometry. The error bar is the standard error of the mean of three biological replicates. Asterisks (*) indicate statistically significant differences between infected MB and VB samples $(P<0.05)$, using unpaired heteroscedastic Student's $t$ test. C and D, Penetration pegs (arrowheads) from appressoria were stopped by papillae formation (arrows) in VB (C) but not in MB (D). ap = appressorium, $\mathrm{c}=$ cuticle, ep = epidermis, hc = hypodermal cell, and $\mathrm{h}=$ hyphae. 
CWDE and sugar-type MFS transporters (Amselem et al. 2011), suggesting that, in both interactions, a metabolism shift occurs to degrade and feed on the host tissues. Other transcriptomic studies investigating the interaction between $B$. cinerea and some of its host plants were not designed to compare in vitro versus in planta fungal gene expression. Nevertheless, comparison of the lists of the 200 most highly expressed $B$. cinerea genes in the array-based transcriptome of infected bean leaves (Phaseolus vulgaris, $48 \mathrm{hpi}$ ) (Schumacher et al. 2012), and the RNAseq-based transcriptome analysis of infected lettuce (Lactuca sativa, 12, 24, and $48 \mathrm{hpi}$ ) (De Cremer et al. 2013) and infected tomato leaves (Solanum lycopersicoides, 24 and $48 \mathrm{hpi}$ ) (Smith et al. 2014), allowed us to identify a number of genes that were also highlighted in our study (i.e., those encoding the aspartic protease AP8, SOD1, and the secondary metabolism gene clusters responsible for botrydial and botcinic acid synthesis). Finally, a study published by BlancoUlate et al. (2014) demonstrated that B. cinerea expresses a common set of CWDE when infecting tomato, grapevine fruits, or lettuce but may also attack more unusual host wall polysaccharide substrates with specific enzymes, depending on the host tissue. All together, these results and ours suggest that some common proteolytic, oxidative, and phytotoxic activities of $B$. cinerea are similarly induced on different hosts, while other virulencerelated functions would be crucial only in some hosts. Recent examples of the latter are the catabolism of D-galacturonic acid (Zhang and van Kan 2013) and arabinan (Nafisi et al. 2014).

One of the main objectives of this study was to investigate why the grape berries at the veraison stage (VB) are highly resistant to $B$. cinerea, while the $\mathrm{MB}$ are highly susceptible. Both our microscopic observations and expression analyses of a set of six fungal genes related to virulence, suggested that B. cinerea initiated its infection program both on $\mathrm{VB}$ and on $\mathrm{MB}$. Germinated conidia formed appressoria, and the expression of the BcPg2, BcPme2, BcNep2, BcSod1, BcGst1, and BcBoa6 genes was induced at 16 and $24 \mathrm{hpi}$. Our data also demonstrated that further infection in VB is halted by cell-wall reinforcement and formation of papillae just underneath the appressoria. Gene expression, microscopic, and metabolite analyses indicated that this defense process is based on localized $\mathrm{H}_{2} \mathrm{O}_{2}$ production and lignin synthesis. In grapevine, the production of $\mathrm{O}_{2}{ }^{-}-$could be explained by the upregulation of the $V v R b o h D$ gene, while its conversion into $\mathrm{H}_{2} \mathrm{O}_{2}$ could rely on the upregulation of the $V v G l p 3$ gene (Godfrey et al. 2007). Genetic evidence for Rboh function in the pathogen-induced oxidative burst has been provided by knocking down the Rboh gene in different plant species. Double mutants of Arabidopsis AtrbohD and AtrbohF genes show greatly reduced ROS production in response to infection by avirulent Pseudomonas syringae pv. tomato DC3000 and Hyaloperonospora parasitica (Torres et al. 2002). Similarly, NbRboh-silenced Nicotiana benthamiana plants show a reduced oxidative burst and disease resistance to Phytophthora infestans (Yoshioka et al. 2003). The production of $\mathrm{H}_{2} \mathrm{O}_{2}$ and lignin at the site of $B$. cinerea inoculation was also observed in green tomatoes, which are resistant to gray mold (Cantu et al. 2009). Moreover, the tomato sitiens mutant, which is highly resistant to B. cinerea, shows a primed $\mathrm{H}_{2} \mathrm{O}_{2}$ accumulation, PRI overexpression, and cell-wall reinforcement in the epidermal cells (Asselbergh et al. 2007). In Arabidopsis leaves infected with $B$. cinerea, the microarray data analysis also revealed a clear induction of a cluster of genes involved in the lignin biosynthesis at 24 and 48 hpi (Ferrari et al. 2007). The fact that the AtRbohD mutant is unable to make any $\mathrm{H}_{2} \mathrm{O}_{2}$ or lignin deposition provides genetic evidence that lignin synthesis needs the RbohD-mediated $\mathrm{H}_{2} \mathrm{O}_{2}$ production (Denness et al. 2011). Our results indicate that the localized $\mathrm{H}_{2} \mathrm{O}_{2}$ production by SOD-like activities (VvGLP3) (Godfrey et al. 2007) is linked to lignification processes that block the penetration of the appressorium by papillae formation.
Grape berries infected with $B$. cinerea are known to activate the production of stilbenes (Jeandet et al. 1995), including the resveratrol phytoalexin that inhibits $B$. cinerea growth (Schouten et al. 2002; Zheng et al. 2011). Our results are consistent with those of Bavaresco et al. (1997) showing that infected VB but not MB activate the production of resveratrol. We also confirmed that the genes involved in the biosynthesis (STS and $P A L$ ) are upregulated in inoculated berries, as previously suggested by semiquantitative PCR (Kretschmer et al. 2007). In the same way, transgenic grapevine plantlets overexpressing the STS gene are more resistant to $B$. cinerea (Coutos-Thévenot et al. 2001). In Arabidopsis, the PAD3 gene, encoding a cytochrome P450 involved in synthesis of the camalaxin phytoalexin, was significantly induced during B. cinerea infection (Ferrari et al. 2007; Zhou et al. 1999). Camalexin induces programmed cell death in $B$. cinerea (Shlezinger et al. 2011) and, consequently, the Arabidopsis pad3 mutant is more susceptible to $B$. cinerea (Galletti et al. 2008; Rowe et al. 2010). All together, these data suggest that phytoalexin production is a common plant defense pathway involved in resistance against this necrotrophic pathogen.

As suggested by the presented transcriptomic data and metabolite analysis, the SA pathway might also participate in basal resistance in VB. This observation contradicts the common dogma in A. thaliana, in which the SA- and the JA/ET- pathways are associated with defense against biotrophic and necrotrophic pathogens, respectively (Glazebrook 2005). If Arabidopsis mutants impaired in JA (coil, aos1) and ET (ein2) are more susceptible to $B$. cinerea, it's interesting to note that transgenic plants overexpressing the bacterial $n a h G$ gene (which inhibits the accumulation of SA) are also more susceptible to B. cinerea (Ferrari et al. 2003, 2007; Rowe et al. 2010). Moreover, SA or its analog benzothiadiazole (BTH) induces resistance to $B$. cinerea in Arabidopsis, tomato, or sunflower (Audenaert et al. 2002; De Meyer et al. 1999; Dmitriev et al. 2003; Ferrari et al. 2003; Murphy et al. 2000). Last, the treatment of grapevine berries with BTH triggers protection against $B$. cinerea (Iriti et al. 2005), and the SA marker gene $V v P R 1$ was shown to be upregulated when grapevine leaves were treated with $B$. cinerea elicitors (Repka 2006). In the resistant $\mathrm{VB}$, the $\mathrm{SA}$-dependent marker gene $V v P R 1$ was significantly induced during $B$. cinerea infection, whereas $V v J A Z 1$, which is a marker of the JA-dependent pathway, was not. Similarly the amount of JA-Ile was not significantly induced during $B$. cinerea infection on VB.

In Arabidopsis, tomato, or $N$. benthamiana plant leaves, a finely tuned cross-talk network of signals involving JA, SA, but also ABA seems to be important for resistance to $B$. cinerea (Asselbergh et al. 2007; Ferrari et al. 2003, 2007; Glazebrook 2005; Rowe et al. 2010). Quantification of the ABA amount by LC-MS showed a similar slight decrease during $B$. cinerea infection on VB and MB (Supplementary Fig. S2). Thus, on $\mathrm{VB}$, only the activation of the SA-dependent pathway is correlated to resistance against $B$. cinerea.

In conclusion, the data obtained both on the fungal and the plant sides demonstrated that a true interaction occurs between VB and B. cinere $a$ and that grapevine possesses efficient defense mechanisms to block gray mold disease at the phenologic VB stage. These efficient defense mechanisms involve localized $\mathrm{H}_{2} \mathrm{O}_{2}$ production, activation of SA-dependent defense genes, and genes involved in stilbene and lignin biosynthesis. Hence, there is an accumulation of caffeic, ferulic, and chlorogenic acids, allowing the formation of papillae, and of resveratrol. Together, these mechanical and chemical defenses block $B$. cinerea from invading the VB skin epidermal layer. Interestingly, while many defense mechanisms are activated upon $B$. cinerea inoculation on $\mathrm{VB}$, our microarray data demonstrated that, in inoculated $\mathrm{MB}$, a 
very different transcriptome is activated. Part of the difference was caused by activation of the JA-dependent defense pathway. Despite this activation at $24 \mathrm{hpi}, \mathrm{MB}$ are highly susceptible to gray mold disease. It is well-known that ripening involves significant changes in the physiological and biochemical properties of grape berries (Dai et al. 2013) and therefore influences the course of infection by pathogens. The relation between fruit ripening and susceptibility to $B$. cinerea has been mainly investigated in tomato. Modifications of the tomato cell wall during ripening contribute to susceptibility to gray mold (Cantu et al. 2008). Transcriptomic data even suggested that $B$. cinerea would induce the expression of tomato genes involved in ripening in order to favor its development (Cantu et al. 2009). Our study seems to indicate that, in grapevine, ripening is associated with a drastic shift in defense mechanisms against gray mold from a SAdependent pathway at VB to a JA-dependent one in MB.

\section{MATERIALS AND METHODS}

\section{Grape berry inoculations.}

All VB and MB used in this study belong to the cultivar Marselan and were collected from the same experimental INRA vineyard near Bordeaux between 2009 and 2013 (Supplementary Table S5). VB were sampled from clusters showing approximately $10 \%$ of the berries having changed color (beginning of veraison, stage 35, according to Eichorn and Lorenz [1977]). Visually healthy berry bunches were randomly collected from a total of 25 cultivation rows. Individual berries were washed for 45 min under running tap water supplemented with three drops per liter of Tween 80 every $5 \mathrm{~min}$, followed by $15 \mathrm{~min}$ of washing under running deionized water.

The $B$. cinerea inoculum was produced by growing strain B05-10 (Quidde et al. 1998) on solid medium (1.5\% malt extract, $0.5 \%$ glucose, $0.1 \%$ tryptone, $0.1 \%$ casein hydrolysate, $0.1 \%$ yeast extract, and $0.02 \%$ tRNA), first, for 5 days in the dark, followed by 5 days under black light ( 300 to $400 \mathrm{~nm}$ ) to promote fungal sporulation (OSRAM L36-73; 10-h day and 14-h night).

For microscopic and transcriptomic analysis, the equatorial area of each berry was inoculated with three inoculum droplets spotted in a triangle, each of $10 \mu \mathrm{l}$ with 5,000 conidia, in potato dextrose browth (PDB) (1 $\mathrm{g}$ of potato starch per liter, $5 \mathrm{~g}$ of dextrose per liter; Duchefa Biochimie). The inoculated berries were kept in clear plastic boxes in $100 \%$ relative humidity in a growth chamber with fluorescent light tubes (CONVIRON ATC26; $\mathrm{T}=20^{\circ} \mathrm{C}$, light intensity $75 \mu \mathrm{E} \mathrm{s}^{-1} \mathrm{~m}^{-2}, 12-\mathrm{h}$ day and 12-h night). The 0,24 , and 48 hpi peel samples (without pulp, i.e., exocarp) were collected $2 \mathrm{~h}$ before the onset of the dark period and the 16-hpi samples $2 \mathrm{~h}$ after the onset of the light period. The exocarp of the inoculated area (diameter of $5 \mathrm{~mm}$ ) from 60 berries was used per RNA sample. Triplicate biological experiments were realized with $\mathrm{VB}$ and $\mathrm{MB}$ and were repeated in independent years. After sampling for microscopic and transcriptomic analyses, remaining berries were observed every day and the disease symptoms quantified until 13 dpi. The rate of berries bursting and the percentage of berries showing $\mathrm{Bo}$ trytis conidiophores were measured on 180 berries per modality (triplicate of 60 mock- or Botrytis-inoculated berries).

For the pathotests of the $B$. cinerea KO mutants, 18 mature berries were inoculated with 5,000 conidia in $10 \mu \mathrm{l}$ of PDB and were incubated at $16^{\circ} \mathrm{C}$. The rate of bursting and sporulation was measured daily. The experiments were repeated three times with berries harvested between 2011 and 2013.

\footnotetext{
Microscopy of $B$. cinerea mycelium development on berries tissues.

Berries exocarp segments $(2 \times 7 \mathrm{~mm})$ were excised from inoculation points (three segments per berry) and were fixed
}

immediately in $2.5 \%$ glutaraldehyde (in $0.1 \mathrm{M}$ sodiumcacodylate buffer, $\mathrm{pH} 7.2$ ) for 20 to 25 min under vacuum, and then, overnight at $4^{\circ} \mathrm{C}$ with gentle rotation. Samples were twice washed $(10 \mathrm{~min})$ in the same buffer and were postfixed in $1 \%$ osmium tetroxide $\left(\mathrm{OsO}_{4}\right)$ in the same buffer for $1 \mathrm{~h}$ at $4{ }^{\circ} \mathrm{C}$. Then, samples were washed in cacodylate buffer, were dehydrated in a graded ethanol series, and were treated with propylene oxide. Dehydrated samples were subsequently embedded in Epon (Merck, Darmstadt, Germany) and were sectioned using a Reichert Ultracut E microtome (Leica, Reuil-Malmaison, France) with glass knife (Diatome, Bienne, Switzerland). The semithin $(0.5 \mu \mathrm{m})$ sections were stained with $1 \%$ aqueous toluidine blue (in $1 \%$ sodium tetraborate) and were examined under a bright-field light microscope (Leica).

For scanning microscopy, berries exocarp disks $(7 \mathrm{~mm}$ in diameter) were excised and were fixed with $2 \%$ glutaraldehyde (in $0.1 \mathrm{M}$ phosphate buffer, $\mathrm{pH}$ 7.2) for $1 \mathrm{~h}$ under vacuum, and then, overnight at $4^{\circ} \mathrm{C}$ with gentle rotation. Disks were washed three times in phosphate buffer, were dehydrated in a graded ethanol series at $4^{\circ} \mathrm{C}$, critical point dried (Critical Point Dryer, Emscope CDP750; Ashford, England), and were coated with gold. Samples were observed with a scanning electron microscope (Philips XL-30 ESEM LaB6).

For subcellular localization of $\mathrm{H}_{2} \mathrm{O}_{2}$, berries inoculated by B. cinerea or mock-inoculated (PDB medium) were harvested at $72 \mathrm{hpi}$ and were then infiltrated by $1 \mathrm{mg}$ of DAB-HCl per milliliter. For this step, disposable 5-ml syringes, fitted with $0.45 \mathrm{~mm}$ diameter needles, were used in order to inject DAB droplets into the exocarp and the mesocarp of the detached berries. Three injections were performed, dispatched all around the fruit. Absorption and polymerization of DAB was confirmed by dark staining (reddish-brown) of the vascular and wound tissues. After $5 \mathrm{~h}$ at $25^{\circ} \mathrm{C}, 7 \mathrm{~mm}$ diameter pieces were excised in the exocarp, were put overnight in absolute methanol, and were then transferred into chloral hydrate solution $(2.5 \mathrm{~g} / \mathrm{ml})$ overnight at room temperature to clarify the tissues. The berry disks were then mounted on microscope slides in 50\% glycerol (aqueous solution), with the epidermis uppermost. $\mathrm{H}_{2} \mathrm{O}_{2}$ was visualized as a reddish-brown coloration.

\section{RNA preparation.}

RNA was extracted from grape tissues and from $B$. cinerea mycelium with a protocol modified from Reid et al. (2006). Prewarmed $\left(60^{\circ} \mathrm{C}\right)$ extraction buffer consisting of $300 \mathrm{mM}$ Tris- $\mathrm{HCl}$ (pH 8), $25 \mathrm{mM}$ EDTA, $2 \mathrm{M} \mathrm{NaCl}, 1 \mathrm{mM}$ aurintricarboxylic acid, $2 \%$ hexadecyl-trimethyl-ammonium bromide, $2 \%$ polyvinylpolypyrrolidone, $0.05 \%$ spermidine trihydrochloride, and $2 \% \beta$-mercaptoethanol was added to frozen berry peel powder at $15 \mathrm{ml} / \mathrm{g}$ and was shaken vigorously. Samples were incubated in a $60^{\circ} \mathrm{C}$ water bath for $10 \mathrm{~min}$ and shaken every $2 \mathrm{~min}$. An equal volume of chloroform/3-methyl-1-butanol (24:1) was added and samples were mixed vigorously, followed by centrifugation at $3,500 \times g$ for $15 \mathrm{~min}$ at $4^{\circ} \mathrm{C}$. The water phase was collected and subjected to a repeated chloroform extraction. Nucleic acids in the water phase were precipitated in $0.3 \mathrm{M}$ sodium acetate $(\mathrm{pH} 5.2)$ and by adding $0.6 \mathrm{vol}$ of isopropyl alcohol. After $1 \mathrm{~h}$ at $-20^{\circ} \mathrm{C}$, the precipitates were pelleted by centrifugation at $3,500 \times g$ for $30 \mathrm{~min}$ at $4^{\circ} \mathrm{C}$, and the pellet was dissolved in $1 \mathrm{ml}$ of TE buffer $(10 \mathrm{mM}$ Tris$\mathrm{HCl}, \mathrm{pH} 8,1 \mathrm{mM}$ EDTA). $\mathrm{LiCl}$ was added to $2.5 \mathrm{M}$ and large RNAs were precipitated overnight at $4^{\circ} \mathrm{C}$ and were pelleted by centrifugation at $20000 \times g$ for $30 \mathrm{~min}$ at $4^{\circ} \mathrm{C}$. The pellet was washed with $70 \%$ ethanol and was dissolved in water. Remaining traces of DNA were removed by DNaseI treatment (DNA-free; Invitrogen, Life Technologies, Saint-Aubin, France) and the RNA quality was analyzed using a RNA 6000 nano kit (Agilent Technologies, Waldbronn, Germany). 


\section{B. cinerea array hybridization and data analysis.}

The complete transcriptome of $B$. cinerea was investigated both during the infection of grape berries $(12,24$, and $48 \mathrm{hpi})$ or after $48 \mathrm{~h}$ of in vitro mycelium development on synthetic medium (per liter: $20 \mathrm{~g}$ of glucose, $2 \mathrm{~g}$ of $\mathrm{NaNO}_{3}, 1 \mathrm{~g}$ of $\mathrm{KH}_{2} \mathrm{PO}_{4}, 0.5 \mathrm{~g}$ of $\mathrm{MgSO}_{4}, 7 \mathrm{H}_{2} \mathrm{O}, 0.5 \mathrm{~g}$ of $\mathrm{KCl}, 0.01 \mathrm{~g}$ of $\mathrm{FeSO}_{4}, 7 \mathrm{H}_{2} \mathrm{O}$ ) with the same light conditions as for the infected berries. Synthesis of double-stranded cDNA, Cy3labeling, and hybridization on microarrays were done by PartnerChip (Evry, France), using the procedures established by NimbleGen (Roche, Mannheim, Germany) and the reagents from Invitrogen. NimbleGen 4-plex arrays with 62,478 60-mer specific probes covering all the 20,885 predicted gene models of B. cinerea (Amselem et al. 2011) were used. Details of experiments and raw values are available in the Gene Expression Omnibus database (GEO) under the entry GSE65559. Data processing, quality controls, and differential expression analysis were performed using ANAIS methods (Simon and Biot 2010). DE genes were identified using oneway ANOVA with the false discovery rate (FDR) test for multiple tests correction of ANOVA $P$ values. Transcripts with a corrected $P$ value $<0.05$ and more than a twofold change in transcript level were considered as significantly differentially expressed. The expression patterns for the DE genes were clustered with Genesis software (Sturn et al. 2002). Gene set enrichment analyses (Fisher's exact test) were further performed on lists of annotated genes (Amselem et al. 2011).

\section{Grape array hybridization and data analysis.}

The cDNA synthesis, labeling, hybridization, and washing steps were performed according to the NimbleGen Arrays User's Guide (version 3.2). Each sample was hybridized to a NimbleGen microarray 090818 Vitis exp HX12 (Roche, NimbleGen), which contains probes targeted to 29,549 predicted grapevine genes, representing $98.6 \%$ of the genes predicted from the $\mathrm{V} 1$ annotation of the $12 \times$ grapevine genome. Each microarray was scanned using an Axon GenePix 4400A (Molecular Devices, Sunnyvale, CA, U.S.A.) at $532 \mathrm{~nm}$ (Cy3 absorption peak) and GenePix Pro7 software (Molecular Devices). Images were analyzed using NimbleScan v2.5 software (Roche), which produces pair files containing the raw signal intensity data for each probe and calls files with normalized expression data derived from the average of the intensities of the four probes for each gene. All microarray expression data are available in the GEO under the entry GSE65969. The statistically significant transcripts from the grapevine microarray data were detected using ANAIS with the FDR test for multiple tests correction of ANOVA $P$ values (Simon and Biot 2010). Transcripts with a fold change greater than 2 and $P$ value $<0.05$ were considered significant. Hierarchical clustering of significant berry transcripts was done with MeV software (Saeed et al. 2006). The GO analysis of the individual gene clusters was done with agriGO, with the Fisher's exact test and the FDR test as chosen statistical tests $(P<0.05)$ (Du et al. 2010).

\section{qPCR.}

For the qPCR, cDNA was synthesized using Superscript III reverse transcription (Invitrogen), oligo(dT) primers, and 1,5 $\mu \mathrm{g}$ of DNA-free total RNA, according to the manufacturer's instructions. The 5- $\mu \mathrm{l}$ reactions $(2 \mu \mathrm{l}$ of 1:80 diluted cDNA, $2.5 \mu \mathrm{l}$ GoTaq qPCR master mix [Promega, Madison, WI, U.S.A.], and a final primer concentration of $500 \mathrm{nM}$ ) were run in a LightCycler 480 (Roche) using a thermal cycling profile of $95^{\circ} \mathrm{C}$ for $15 \mathrm{~min}, 40$ to 50 cycles of $95^{\circ} \mathrm{C}$ for $30 \mathrm{~s}, 60^{\circ} \mathrm{C}$ for $30 \mathrm{~s}$, and $72^{\circ} \mathrm{C}$ for $30 \mathrm{~s}$. Each assay was tested in a dissociation protocol to ensure a single amplicon was produced. The primer pair efficiency was taken into account by using the N0 values of the LinRegPCR program (Ruijter et al. 2009) in relative induction value calculations. VvATP16 and BcActl were used as the reference genes for $V$. vinifera and B. cinerea, respectively (Gamm et al. 2011; Simon et al. 2013). All primers and corresponding gene identifiers can be found in Supplementary Table S6 and in other previous publications (Trdá et al. 2014; Schumacher et al. 2015). Statistical significance was calculated with a Student's heteroscedastic $t$ test considering each technical replicate as an individual sample $(n=9)$.

\section{B. cinerea mutagenesis.}

The $B$. cinerea gene $B c P k s 8$ (Kroken et al. 2003) was deleted by homologous recombination. Pairs of primers $5 \mathrm{~F}$ and $5 \mathrm{R}$ were used to amplify regions of about $1 \mathrm{~kb}$ in the $5^{\prime}$ and in the $3^{\prime}$ regions of the target gene and the hygromycin resistance gene $(h p h)$ (Supplementary Table S7). Then, a KO cassette consisting of the $5^{\prime}$ region of $B c P k s 8$, the resistance gene and the 3' region of $B c P k s 8$ was generated with the Gene KO kit obtained from the Fungal Genetic Stock Center (Colot et al. 2006). Protoplasts from the B05.10 strain were prepared and transformed as previously described (Simon et al. 2013). They were then plated in molten osmotically stabilized medium agar containing $100 \mu \mathrm{g}$ of hygromycin per milliliter (Invitrogen). Transformants were purified by single-spore cultures. The screenings for gene inactivation events were done by PCR, using the primers located outside the cassette flanking regions (verif-5 and verif-3) and primers located inside the resistance gene $h p h$. Additionally, the genetic purity of the KO transformants was checked by the absence of the WT allele (primers Fint and Rint). Information about published $B$. cinerea $\mathrm{KO}$ mutants used in this study is available at INRA's Botrytis cinerea mutants database.

\section{Grape metabolites.}

To determine changes in JA, SA, ferulic acid, caffeic acid, and chlorogenic acid levels upon inoculation, peel discs from the mock-infected or infected grapevine berries were collected and were frozen immediately in liquid nitrogen. Before extraction, a mixture of internal standards containing $100 \mathrm{ng}$ of dihydrojasmonic acid, d6-SA, and propyl-paraben was added. Freeze-dried tissue $(0.05 \mathrm{~g})$ was homogenized in $2.5 \mathrm{ml}$ of ultrapure water; after centrifugation $(5,000 \times \mathrm{g}, 40 \mathrm{~min})$, the supernatant was recovered acidified and partitioned against diethylether as described by Flors et al. (2008). The dried organic phase was resuspended in $1 \mathrm{ml}$ of a water/methanol (90:10) solution and an aliquot was injected into the high-performance liquid chromatography (HPLC) system. Analyses were carried out using a Waters Alliance 2690 HPLC system (Milford, MA, U.S.A.) with nucleosil ODS reversed-phase column $(100 \times 2 \mathrm{~mm}$ i.d.; $5 \mathrm{~lm}$ ) (Scharlab, Barcelona, Spain). The chromatographic system was interfaced to a Quatro LC (quadrupole-hexapolequadrupol). Compound quantities were compared with their respective standard curves for all metabolites. Quantifications were carried out with Mass Lynx (v 1.4, Micromass) software using the internal standards as reference for extraction recovery and the standard curves as quantifiers.

The resveratrol phytoalexin was quantified in an aliquot of the previously described aqueous extract. The chromatography was carried out in the same conditions used for hormonal measurements using gradients of water and methanol, both phases containing $0.01 \%$ of $\mathrm{HCOOH}$, as described by Flors et al. (2008). The mass spectrometer was programmed to detect transitions from m/z 227.1 to m/z 143.1 for resveratrol. Relative retention time was 10.06 for resveratrol. All compounds were quantified using a calibration curve built with their respective standards. 


\section{ACKNOWLEDGMENTS}

We are grateful to the Agence National de la Recherche (ANR) and to the Comité National des Interprofessions des Vins à Appellation d'Origine (CNIV) for their financial support (grant PCS-08-GENO-148 SafeGrape) We also thank the Bordeaux experimental INRA vineyard of Château Couhins for providing the harvested berries, P. Tudzynski (University of Muenster, Germany) for providing the B. cinerea bcsodl 1 and bcabal mutants, and the Servicios Centrales de Instrumentación Científica of the Universitat Jaume I for the use of its facilities and its technical advices. J. Kelloniemi was financially supported by the "Conseil Regional de Bourgogne" (Dinos-Agrale 12, grant 2010-9201AAO050S5542). We also wish to thank the Microscopy Center INRA/uB of the DimaCell platform and, more particularly, A. Bonnotte for her technical assistance with SEM.

\section{LITERATURE CITED}

Amselem, J., Cuomo, C. A., van Kan, J. A., Viaud, M., Benito, E. P., Couloux, A., Coutinho, P. M., de Vries, R. P., Dyer, P. S., Fillinger, S., Fournier, E., Gout, L., Hahn, M., Kohn, L., Lapalu, N., Plummer, K. M., Pradier, J. M., Quévillon, E., Sharon, A., Simon, A., ten Have, A., Tudzynski, B., Tudzynski, P., Wincker, P., Andrew, M., Anthouard, V., Beever, R. E., Beffa, R., Benoit, I., Bouzid, O., Brault, B., Chen, Z., Choquer, M., Collémare, J., Cotton, P., Danchin, E. G., Da Silva, C., Gautier, A., Giraud, C., Giraud, T., Gonzalez, C., Grossetete, S., Güldener, U., Henrissat, B., Howlett, B. J., Kodira, C., Kretschmer, M., Lappartient, A., Leroch, M., Levis, C., Mauceli, E., Neuvéglise, C., Oeser, B., Pearson, M., Poulain, J., Poussereau, N., Quesneville, H., Rascle, C., Schumacher, J., Ségurens, B., Sexton, A., Silva, E., Sirven, C., Soanes, D. M., Talbot, N. J., Templeton, M., Yandava, C., Yarden, O. Zeng, Q., Rollins, J. A., Lebrun, M. H., and Dickman, M. 2011. Genomic analysis of the necrotrophic fungal pathogens Sclerotinia sclerotiorum and Botrytis cinerea. PLoS Genet. 7:e1002230.

Asselbergh, B., Curvers, K., Franca, S. C., Audenaert, K., Vuylsteke, M., Van Breusegem, F., and Höfte, M. 2007. Resistance to Botrytis cinerea in sitiens, an abscisic acid-deficient tomato mutant, involves timely production of hydrogen peroxide and cell wall modifications in the epidermis. Plant Physiol. 144:1863-1877.

Audenaert, K., De Meyer, G. B., and Höfte, M. M. 2002. Abscisic acid determines basal susceptibility of tomato to Botrytis cinerea and suppresses salicylic acid-dependent signaling mechanisms. Plant Physiol. 128:491-501.

Bavaresco, L., Petegolli, D., Cantu, E., Fregoni, M., Chiusa, G., and Trevisan, M. 1997. Elicitation and accumulation of stilbene phytoalexins in grapevine berries infected by Botrytis cinerea. Vitis 36:77-83.

Bézier, A., Lambert, B., and Baillieul, F. 2002. Cloning of a grapevine Botrytis-responsive gene that has homology to the tobacco hypersensitivity-related $h s r 203 J$. J. Exp. Bot. 53:2279-2280.

Blanco-Ulate, B., Morales-Cruz, A., Amrine, K. C., Labavitch, J. M., Powell, A. L., and Cantu, D. 2014. Genome-wide transcriptional profiling of Botrytis cinerea genes targeting plant cell walls during infections of different hosts. Front. Plant Sci. 5:435

Böhm, H., Albert, I., Fan, L., Reinhard, A., and Nürnberger, T. 2014. Immune receptor complexes at the plant cell surface. Curr. Opin. Plant Biol. 20:47-54

Boller, T., and Felix, G. 2009. A renaissance of elicitors: Perception of microbe-associated molecular patterns and danger signals by patternrecognition receptors. Annu. Rev. Plant Biol. 60:379-406.

Bradley, D. J., Kjellbom, P., and Lamb, C. J. 1992. Elicitor- and woundinduced oxidative cross-linking of a proline-rich plant cell wall protein: A novel, rapid defense response. Cell 70:21-30.

Brady, J. D., and Fry, S. C. 1997. Formation of di-isodityrosine and loss of isodityrosine in the cell walls of tomato cell-suspension cultures treated with fungal elicitors or $\mathrm{H}_{2} \mathrm{O}_{2}$. Plant Physiol. 115: 87-92.

Cantarel, B. L., Coutinho, P. M., Rancurel, C., Bernard, T., Lombard, V., and Henrissat, B. 2009. The carbohydrate-active enzymes database (CAZy): An expert resource for glycogenomics. Nucleic Acids Res. 37:D233-D238.

Cantu, D., Blanco-Ulate, B., Yang, L., Labavitch, J. M., Bennett, A. B., and Powell, A. L. 2009. Ripening-regulated susceptibility of tomato fruit to Botrytis cinerea requires NOR but not RIN or ethylene. Plant Physiol. 150:1434-1449.

Cantu, D., Vicente, A. R., Greve, L. C., Dewey, F. M., Bennett, A. B., Labavitch, J. M., and Powell, A. L. 2008. The intersection between cell wall disassembly, ripening, and fruit susceptibility to Botrytis cinerea. Proc. Natl. Acad. Sci. U.S.A. 105:859-864.
Choquer, M., Fournier, E., Kunz, C., Levis, C., Pradier, J. M., Simon, A., and Viaud, M. 2007. Botrytis cinerea virulence factors: New insights into a necrotrophic and polyphageous pathogen. FEMS Microbiol. Lett. 277:1-10.

Colot, H. V., Park, G., Turner, G. E., Ringelberg, C., Crew, C. M., Litvinkova, L., Weiss, R. L., Borkovich, K. A., and Dunlap, J. C. 2006. A high-throughput gene knockout procedure for Neurospora reveals functions for multiple transcription factors. Proc. Natl. Acad. Sci. U.S.A. 103:10352-10357.

Coutos-Thévenot, P., Poinssot, B., Bonomelli, A., Yean, H., Breda, C., Buffard, D., Esnault, R., Hain, R., and Boulay, M. 2001. In vitro tolerance to Botrytis cinerea of grapevine 41B rootstock in transgenic plants expressing the stilbene synthase Vst 1 gene under the control of a pathogen-inducible PR 10 promoter. J. Exp. Bot. 52:901-910.

Dai, Z. W., Léon, C., Feil, R., Lunn, J. E., Delrot, S., and Gomès, E. 2013. Metabolic profiling reveals coordinated switches in primary carbohydrate metabolism in grape berry (Vitis vinifera L.), a non-climacteric fleshy fruit. J. Exp. Bot. 64:1345-1355.

Dalmais, B., Schumacher, J., Moraga, J., LE Pêcheur, P., Tudzynski, B., Collado, I. G., and Viaud, M. 2011. The Botrytis cinerea phytotoxin botcinic acid requires two polyketide synthases for production and has a redundant role in virulence with botrydial. Mol. Plant Pathol. 12: 564-579.

De Cremer, K., Mathys, J., Vos, C., Froenicke, L., Michelmore, R. W., Cammue, B. P., and De Coninck, B. 2013. RNAseq-based transcriptome analysis of Lactuca sativa infected by the fungal necrotroph Botrytis cinerea. Plant Cell Environ. 36:1992-2007.

De Meyer, G., Capieau, K., Audenaert, K., Buchala, A., Métraux, J. P., and Höfte, M. 1999. Nanogram amounts of salicylic acid produced by the rhizobacterium Pseudomonas aeruginosa 7NSK2 activate the systemic acquired resistance pathway in bean. Mol. Plant-Microbe Interact. 12: 450-458.

Dean, R., Van Kan, J. A., Pretorius, Z. A., Hammond-Kosack, K. E., Di Pietro, A., Spanu, P. D., Rudd, J. J., Dickman, M., Kahmann, R., Ellis, J., and Foster, G. D. 2012. The top 10 fungal pathogens in molecular plant pathology. Mol. Plant Pathol. 13:414-430.

Denness, L., McKenna, J. F., Segonzac, C., Wormit, A., Madhou, P., Bennett, M., Mansfield, J., Zipfel, C., and Hamann, T. 2011. Cell wall damage-induced lignin biosynthesis is regulated by a reactive oxygen species- and jasmonic acid-dependent process in Arabidopsis. Plant Physiol. 156:1364-1374.

Denoux, C., Galletti, R., Mammarella, N., Gopalan, S., Werck, D., De Lorenzo, G., Ferrari, S., Ausubel, F. M., and Dewdney, J. 2008. Activation of defense response pathways by OGs and Flg22 elicitors in Arabidopsis seedlings. Mol. Plant 1:423-445.

Derckel, J. P., Audran, J. P., Haye, B., Lambert, B., and Legendre, L. 1998. Characterization, induction by wounding and salicylic acid, and activity against Botrytis cinerea of chitinases and Beta-1,3-glucanases of ripening grape berries. Physiol. Plant. 104:56-64.

Deytieux-Belleau, C., Geny, L., Roudet, J., Mayet, V., Donèche, B., and Fermaud, M. 2009. Grape berry skin features related to ontogenic resistance to Botrytis cinerea. Eur. J. Plant Pathol. 125:551-563.

Dickman, M. B., Park, Y. K., Oltersdorf, T., Li, W., Clemente, T., and French, R. 2001. Abrogation of disease development in plants expressing animal antiapoptotic genes. Proc. Natl. Acad. Sci. U.S.A. 98:6957-6962.

Dmitriev, A., Tena, M., and Jorrin, J. 2003. Systemic acquired resistance in sunflower (Helianthus annuus L.). Tsitol. Genet. 37:9-15.

Du, Z., Zhou, X., Ling, Y., Zhang, Z., and Su, Z. 2010. agriGO: A GO analysis toolkit for the agricultural community. Nucleic Acids Res. 38 W64-W70.

Dubreuil-Maurizi, C., Trouvelot, S., Frettinger, P., Pugin, A., Wendehenne, D., and Poinssot, B. 2010. $\beta$-Aminobutyric acid primes an NADPH oxidase-dependent reactive oxygen species production during grapevine-triggered immunity. Mol. Plant-Microbe Interact. 23: 1012-1021.

Eichorn, K. W., and Lorenz, D. H. 1977. Phänologische entwicklungsstadien der rebe. Nachrichtenbl. Deut. Pflanzenschutzd. 29:119-120.

Elmer, P. A. G., and Michailides, T. J. 2007. Epidemiology of Botrytis cinerea in orchard and vine crops. Pages 243-272. in: Botrytis: Biology, Pathology and Control. Y. Elad, B. Williamson, P. Tudzynski, and N. Delen, eds. Springer, Dordrecht, The Netherlands.

Espino, J. J., Gutiérrez-Sánchez, G., Brito, N., Shah, P., Orlando, R., and González, C. 2010. The Botrytis cinerea early secretome. Proteomics 10: 3020-3034.

Ferrari, S., Galletti, R., Denoux, C., De Lorenzo, G., Ausubel, F. M., and Dewdney, J. 2007. Resistance to Botrytis cinerea induced in Arabidopsis by elicitors is independent of salicylic acid, ethylene, or jasmonate signaling but requires PHYTOALEXIN DEFICIENT3. Plant Physiol 144:367-379. 
Ferrari, S., Plotnikova, J. M., De Lorenzo, G., and Ausubel, F. M. 2003. Arabidopsis local resistance to Botrytis cinerea involves salicylic acid and camalexin and requires EDS4 and PAD2, but not SID2, EDS5 or PAD4. Plant J. 35:193-205.

Flors, V., Ton, J., van Doorn, R., Jakab, G., García-Agustín, P., and MauchMani, B. 2008. Interplay between JA, SA and ABA signalling during basal and induced resistance against Pseudomonas syringae and Alternaria brassicicola. Plant J. 54:81-92.

Frías, M., González, C., and Brito, N. 2011. BcSpl1, a cerato-platanin family protein, contributes to Botrytis cinerea virulence and elicits the hypersensitive response in the host. New Phytol. 192:483-495.

Galletti, R., Denoux, C., Gambetta, S., Dewdney, J., Ausubel, F. M., De Lorenzo, G., and Ferrari, S. 2008. The AtrbohD-mediated oxidative burst elicited by oligogalacturonides in Arabidopsis is dispensable for the activation of defense responses effective against Botrytis cinerea. Plant Physiol. 148:1695-1706.

Gamm, M., Héloir, M. C., Kelloniemi, J., Poinssot, B., Wendehenne, D., and Adrian, M. 2011. Identification of reference genes suitable for qRTPCR in grapevine and application for the study of the expression of genes involved in pterostilbene synthesis. Mol. Genet. Genomics 285:273-285.

Garcia-Brugger, A., Lamotte, O., Vandelle, E., Bourque, S., Lecourieux, D. Poinssot, B., Wendehenne, D., and Pugin, A. 2006. Early signaling events induced by elicitors of plant defenses. Mol. Plant-Microbe Interact. 19:711-724.

Gauthier, A., Trouvelot, S., Kelloniemi, J., Frettinger, P., Wendehenne, D. Daire, X., Joubert, J. M., Ferrarini, A., Delledonne, M., Flors, V., and Poinssot, B. 2014. The sulfated laminarin triggers a stress transcriptome before priming the SA- and ROS-dependent defenses during grapevine's induced resistance against Plasmopara viticola. PLoS One 9:e88145.

Glazebrook, J. 2005. Contrasting mechanisms of defense against biotrophic and necrotrophic pathogens. Annu. Rev. Phytopathol. 43:205-227.

Godfrey, D., Able, A. J., and Dry, I. B. 2007. Induction of a grapevine germin-like protein (VvGLP3) gene is closely linked to the site of Erysiphe necator infection: A possible role in defense? Mol. PlantMicrobe Interact. 20:1112-1125.

Govrin, E. M., and Levine, A. 2000. The hypersensitive response facilitates plant infection by the necrotrophic pathogen Botrytis cinerea. Curr. Biol. 10:751-757.

Hammerschmidt, R. 1999. Phytoalexins: What have we learned after 60 years? Annu. Rev. Phytopathol. 37:285-306.

Heller, J., and Tudzynski, P. 2011. Reactive oxygen species in phytopathogenic fungi: Signaling, development and desease. Annu. Rev. Phytopathol. 49:369-390.

Iriti, M., Rossoni, M., Borgo, M., and Faoro, F. 2004. Benzothiadiazole enhances resveratrol and anthocyanin biosynthesis in grapevine, meanwhile improving resistance to Botrytis cinerea. J. Agric. Food Chem. 52:4406-4413.

Iriti, M., Rossoni, M., Borgo, M., Ferrara, L., and Faoro, F. 2005. Induction of resistance to gray mold with benzothiadiazole modifies amino acid profile and increases proanthocyanidins in grape: Primary versus secondary metabolism. J. Agric. Food Chem. 53:9133-9139.

Jaillon, O., Aury, J. M., Noel, B., Policriti, A., Clepet, C., Casagrande, A., Choisne, N., Aubourg, S., Vitulo, N., Jubin, C., Vezzi, A., Legeai, F., Hugueney, P., Dasilva, C., Horner, D., Mica, E., Jublot, D., Poulain, J., Bruyère, C., Billault, A., Segurens, B., Gouyvenoux, M., Ugarte, E., Cattonaro, F., Anthouard, V., Vico, V., Del Fabbro, C., Alaux, M. Di Gaspero, G., Dumas, V., Felice, N., Paillard, S., Juman, I., Moroldo, M., Scalabrin, S., Canaguier, A., Le Clainche, I., Malacrida, G., Durand, E., Pesole, G., Laucou, V., Chatelet, P., Merdinoglu, D., Delledonne, M., Pezzotti, M., Lecharny, A., Scarpelli, C., Artiguenave, F., Pè M. E., Valle, G., Morgante, M., Caboche, M., Adam-Blondon, A. F., Weissenbach, J., Quétier, F., and Wincker, P.; French-Italian Public Consortium for Grapevine Genome Characterization. 2007. The grapevine genome sequence suggests ancestral hexaploidization in major angiosperm phyla. Nature 449:463-467.

Jeandet, P., Bessis, R., Sbaghi, M., and Meunier, P. 1995. Production of the phytoalexin resveratrol by grapes as a response to Botrytis attack under natural conditions. J. Phytopathol. 143:135-139.

Jeworutzki, E., Roelfsema, M. R., Anschütz, U., Krol, E., Elzenga, J. T., Felix, G., Boller, T., Hedrich, R., and Becker, D. 2010. Early signaling through the Arabidopsis pattern recognition receptors FLS2 and EFR involves Ca-associated opening of plasma membrane anion channels Plant J. 62:367-378.

Jones, J. D., and Dangl, J. L. 2006. The plant immune system. Nature 444 323-329.

Kars, I., Krooshof, G. H., Wagemakers, L., Joosten, R., Benen, J. A., and van Kan, J. A. 2005a. Necrotizing activity of five Botrytis cinerea endopolygalacturonases produced in Pichia pastoris. Plant J. 43 213-225.

Kars, I., McCalman, M., Wagemakers, L., and VAN Kan, J. A. 2005b. Functional analysis of Botrytis cinerea pectin methylesterase genes by PCR-based targeted mutagenesis: Bcpme 1 and Bcpme 2 are dispensable for virulence of strain B05.10. Mol. Plant Pathol. 6:641-652.

Koornneef, A., and Pieterse, C. M. 2008. Cross talk in defense signaling. Plant Physiol. 146:839-844.

Kretschmer, M., Kassemeyer, H. H., and Hahn, M. 2007. Age-dependent grey mould susceptibility and tissue-specific defence gene activation of grapevine berry skins after infection by Botrytis cinerea. J. Phytopathol. $155: 258-263$

Kroken, S., Glass, N. L., Taylor, J. W., Yoder, O. C., and Turgeon, B. G. 2003. Phylogenomic analysis of type I polyketide synthase genes in pathogenic and saprobic ascomycetes. Proc. Natl. Acad. Sci. U.S.A. 100: $15670-15675$

Ky, I., Lorrain, B., Jourdes, M., Pasquier, G., Fermaud, M., Geny, L., Rey, P., Donèche, B., and Teissedre, P. L. 2012. Assessment of grey mould (Botrytis cinerea) impact on phenolic and sensory quality of Bordeaux grapes, musts and wines for two consecutive vintages. Aust. J. Grape Wine Res. 18:215-226.

López, M. A., Bannenberg, G., and Castresana, C. 2008. Controlling hormone signaling is a plant and pathogen challenge for growth and survival. Curr. Opin. Plant Biol. 11:420-427.

Martinez, F., Dubos, B., and Fermaud, M. 2005. The role of saprotrophy and virulence in the population dynamics of Botrytis cinerea in vineyards. Phytopathology 95:692-700.

Monteiro, S., Barakat, M., Piçarra-Pereira, M. A., Teixeira, A. R., and Ferreira, R. B. 2003. Osmotin and thaumatin from grape: A putative general defense mechanism against pathogenic fungi. Phytopathology 93:1505-1512.

Murphy, A. M., Holcombe, L. J., and Carr, J. P. 2000. Characteristics of salicylic acid-induced delay in disease caused by a necrotrophic fungal pathogen in tobacco. Physiol. Mol. Plant Pathol. 57:47-54.

Nafisi, M., Stranne, M., Zhang, L., van Kan, J. A., and Sakuragi, Y. 2014 The endo-arabinanase BcAra1 is a novel host-specific virulence factor of the necrotic fungal phytopathogen Botrytis cinerea. Mol. Plant-Microbe Interact. 27:781-792.

Pinedo, C., Wang, C. M., Pradier, J. M., Dalmais, B., Choquer, M., Le Pêcheur, P., Morgant, G., Collado, I. G., Cane, D. E., and Viaud, M. 2008. Sesquiterpene synthase from the botrydial biosynthetic gene cluster of the phytopathogen Botrytis cinerea. ACS Chem. Biol. 3: 791-801.

Pitzschke, A., Schikora, A., and Hirt, H. 2009. MAPK cascade signalling networks in plant defence. Curr. Opin. Plant Biol. 12:421-426.

Prins, T. W., Wagemakers, L., Schouten, A., and van Kan, J. A. 2000 Cloning and characterization of a glutathione S-transferase homologue from the plant pathogenic fungus Botrytis cinerea. Mol. Plant Pathol. 1: 169-178.

Quidde, T., Osbourn, A. E., and Tudzynski, P. 1998. Detoxification of $\alpha$-tomatine by Botrytis cinerea. Physiol. Mol. Plant Pathol. 52:151-165.

Reid, K. E., Olsson, N., Schlosser, J., Peng, F., and Lund, S. T. 2006. An optimized grapevine RNA isolation procedure and statistical determination of reference genes for real-time RT-PCR during berry development. BMC Plant Biol. 6:27.

Repka, V. 2006. Early defence responses induced by two distinct elicitors derived from a Botrytis cinerea in grapevine leaves and cell suspensions. Biol. Plant. 50:94-106.

Robert, N., Roche, K., Lebeau, Y., Breda, C., Boulay, M., Esnault, R., and Buffard, D. 2002. Expression of grapevine chitinase genes in berries and leaves infected by fungal or bacterial pathogens. Plant Sci. 162:389-400.

Robinson, S. P., Jacobs, A. K., and Dry, I. B. 1997. A class IV chitinase is highly expressed in grape berries during ripening. Plant Physiol. 114: 771-778.

Rolke, Y., Liu, S., Quidde, T., Williamson, B., Schouten, A., Weltring, K. M., Siewers, V., Tenberge, K. B., Tudzynski, B., and Tudzynski, P. 2004. Functional analysis of $\mathrm{H}_{2} \mathrm{O}_{2}$-generating systems in Botrytis cinerea: The major $\mathrm{Cu}-\mathrm{Zn}$-superoxide dismutase (BCSOD1) contributes to virulence on French bean, whereas a glucose oxidase (BCGOD1) is dispensable. Mol. Plant Pathol. 5:17-27.

Rowe, H. C., Walley, J. W., Corwin, J., Chan, E. K., Dehesh, K., and Kliebenstein, D. J. 2010. Deficiencies in jasmonate-mediated plant defense reveal quantitative variation in Botrytis cinerea pathogenesis. PLoS Pathog. 6:e1000861.

Ruijter, J. M., Ramakers, C., Hoogaars, W. M., Karlen, Y., Bakker, O., van den Hoff, M. J., and Moorman, A. F. 2009. Amplification efficiency: Linking baseline and bias in the analysis of quantitative PCR data Nucleic Acids Res. 37:e45. 
Saeed, A. I., Bhagabati, N. K., Braisted, J. C., Liang, W., Sharov, V., Howe, E. A., Li, J., Thiagarajan, M., White, J. A., and Quackenbush, J. 2006. TM4 microarray software suite. Methods Enzymol. 411:134-193.

Salzman, R. A., Tikhonova, I., Bordelon, B. P., Hasegawa, P. M., and Bressan, R. A. 1998. Coordinate accumulation of antifungal proteins and hexoses constitutes a developmentally controlled defense response during fruit ripening in grape. Plant Physiol. 117:465-472.

Schouten, A., van Baarlen, P., and van Kan, J. A. 2008. Phytotoxic Nep1-like proteins from the necrotrophic fungus Botrytis cinerea associate with membranes and the nucleus of plant cells. New Phytol. 177:493-505.

Schouten, A., Wagemakers, L., Stefanato, F. L., van der Kaaij, R. M., and van Kan, J. A. 2002. Resveratrol acts as a natural profungicide and induces self-intoxication by a specific laccase. Mol. Microbiol. 43:883-894.

Schumacher, J., Pradier, J. M., Simon, A., Traeger, S., Moraga, J., Collado, I. G., Viaud, M., and Tudzynski, B. 2012. Natural variation in the VELVET gene bcvel1 affects virulence and light-dependent differentiation in Botrytis cinerea. PLoS One 7:e47840.

Schumacher, J., Simon, A., Cohrs, K. C., Traeger, S., Porquier, A., Dalmais, B., Viaud, M., and Tudzynski, B. 2015. The VELVET complex in the gray mold fungus Botrytis cinerea: Impact of BcLAE1 on differentiation, secondary metabolism, and virulence. Mol. Plant-Microbe Interact. 28:659-674.

Schumacher, J., Simon, A., Cohrs, K. C., Viaud, M., and Tudzynski, P. 2014. The transcription factor BcLTF1 regulates virulence and light responses in the necrotrophic plant pathogen Botrytis cinerea. PLoS Genet. 10:e1004040.

Shlezinger, N., Minz, A., Gur, Y., Hatam, I., Dagdas, Y. F., Talbot, N. J., and Sharon, A. 2011. Anti-apoptotic machinery protects the necrotrophic fungus Botrytis cinerea from host-induced apoptotic-like cell death during plant infection. PLoS Pathog. 7:e1002185.

Siewers, V., Kokkelink, L., Smedsgaard, J., and Tudzynski, P. 2006. Identification of an abscisic acid gene cluster in the grey mold Botrytis cinerea. Appl. Environ. Microbiol. 72:4619-4626.

Siewers, V., Smedsgaard, J., and Tudzynski, P. 2004. The P450 monooxygenase BcABA1 is essential for abscisic acid biosynthesis in Botrytis cinerea. Appl. Environ. Microbiol. 70:3868-3876.

Siewers, V., Viaud, M., Jimenez-Teja, D., Collado, I. G., Gronover, C. S., Pradier, J. M., Tudzynski, B., and Tudzynski, P. 2005. Functional analysis of the cytochrome P450 monooxygenase gene bcbot1 of Botrytis cinerea indicates that botrydial is a strain-specific virulence factor. Mol. Plant-Microbe Interact. 18:602-612.

Simon, A., and Biot, E. 2010. ANAIS: Analysis of NimbleGen arrays interface. Bioinformatics 26:2468-2469.

Simon, A., Dalmais, B., Morgant, G., and Viaud, M. 2013. Screening of a Botrytis cinerea one-hybrid library reveals a Cys2His 2 transcription factor involved in the regulation of secondary metabolism gene clusters. Fungal Genet. Biol. 52:9-19.

Smith, J. E., Mengesha, B., Tang, H., Mengiste, T., and Bluhm, B. H. 2014. Resistance to Botrytis cinerea in Solanum lycopersicoides involves widespread transcriptional reprogramming. BMC Genomics 15:334.

Sturn, A., Quackenbush, J., and Trajanoski, Z. 2002. Genesis: Cluster analysis of microarray data. Bioinformatics 18:207-208.

ten Have, A., Espino, J. J., Dekkers, E., Van Sluyter, S. C., Brito, N., Kay, J., González, C., and van Kan, J. A. 2010. The Botrytis cinerea aspartic proteinase family. Fungal Genet. Biol. 47:53-65.

Torres, M. A., Dangl, J. L., and Jones, J. D. 2002. Arabidopsis gp91phox homologues AtrbohD and AtrbohF are required for accumulation of reactive oxygen intermediates in the plant defense response. Proc. Natl. Acad. Sci. U.S.A. 99:517-522.

Trdá, L., Fernandez, O., Boutrot, F., Héloir, M. C., Kelloniemi, J., Daire, X., Adrian, M., Clément, C., Zipfel, C., Dorey, S., and Poinssot, B. 2014. The grapevine flagellin receptor VvFLS2 differentially recognizes flagellin-derived epitopes from the endophytic growth-promoting bacterium Burkholderia phytofirmans and plant pathogenic bacteria. New Phytol. 201:1371-1384.

Tsuda, K., and Katagiri, F. 2010. Comparing signaling mechanisms engaged in pattern-triggered and effector-triggered immunity. Curr. Opin. Plant Biol. 13:459-465.

Van Baarlen, P., Woltering, E. J., Staats, M., and Van Kan, J. A. L. 2007. Histochemical and genetic analysis of host and non-host interactions of Arabidopsis with three Botrytis species: An important role for cell death control. Mol. Plant Pathol. 8:41-54.

van Kan, J. A. 2006. Licensed to kill: The lifestyle of a necrotrophic plant pathogen. Trends Plant Sci. 11:247-253.

van Loon, L. C., Rep, M., and Pieterse, C. M. 2006. Significance of inducible defense-related proteins in infected plants. Annu. Rev. Phytopathol. 44:135-162.

Velasco, R., Zharkikh, A., Troggio, M., Cartwright, D. A., Cestaro, A., Pruss, D., Pindo, M., Fitzgerald, L. M., Vezzulli, S., Reid, J., Malacarne, G., Iliev, D., Coppola, G., Wardell, B., Micheletti, D., Macalma, T., Facci, M., Mitchell, J. T., Perazzolli, M., Eldredge, G., Gatto, P., Oyzerski, R., Moretto, M., Gutin, N., Stefanini, M., Chen, Y., Segala, C., Davenport, C., Demattè, L., Mraz, A., Battilana, J., Stormo, K., Costa, F., Tao, Q., Si-Ammour, A., Harkins, T., Lackey, A., Perbost, C., Taillon, B., Stella, A., Solovyev, V., Fawcett, J. A., Sterck, L., Vandepoele, K., Grando, S. M., Toppo, S., Moser, C., Lanchbury, J., Bogden, R., Skolnick, M., Sgaramella, V., Bhatnagar, S. K., Fontana, P., Gutin, A., Van de Peer, Y., Salamini, F., and Viola, R. 2007. A high quality draft consensus sequence of the genome of a heterozygous grapevine variety. PLoS One 2:e1326.

Yoshioka, H., Numata, N., Nakajima, K., Katou, S., Kawakita, K., Rowland, O., Jones, J. D., and Doke, N. 2003. Nicotiana benthamiana gp91phox homologs NbrbohA and NbrbohB participate in $\mathrm{H} 2 \mathrm{O} 2$ accumulation and resistance to Phytophthora infestans. Plant Cell 15: 706-718.

Zhang, L., and van Kan, J. A. 2013. Botrytis cinerea mutants deficient in D-galacturonic acid catabolism have a perturbed virulence on Nicotiana benthamiana and Arabidopsis, but not on tomato. Mol. Plant Pathol. 14: 19-29.

Zheng, C., Choquer, M., Zhang, B., Ge, H., Hu, S., Ma, H., and Chen, S. 2011. LongSAGE gene-expression profiling of Botrytis cinerea germination suppressed by resveratrol, the major grapevine phytoalexin. Fungal Biol. 115:815-832.

Zhou, N., Tootle, T. L., and Glazebrook, J. 1999. Arabidopsis PAD3, a gene required for camalexin biosynthesis, encodes a putative cytochrome P450 monooxygenase. Plant Cell 11:2419-2428.

Zipfel, C. 2014. Plant pattern-recognition receptors. Trends Immunol. 35: 345-351.

\section{AUTHOR-RECOMMENDED INTERNET RESOURCES}

Fungal Genetic Stock Center database: http://www.fgsc.net/clones.html

INRA's Botrytis cinerea mutants database:

http://botbioger.versailles.inra.fr/botmut/index.html 